\title{
Application of Genomics to Clinical Practice in Haematological Malignancy
}

\author{
Coen Veenstra ${ }^{1} \cdot$ David Bruce $^{2} \cdot$ Adele Timbs $^{3} \cdot$ Angela Hamblin $^{4}$
}

Published online: 2 December 2019

(C) The Author(s) 2019

\begin{abstract}
Purpose of Review The usual abundance of fresh cells and high-quality DNA derived from bone marrow aspirate and peripheral blood mean haematological malignancies are at the forefront of the application of genomics to malignancy. This review evaluates where genomics is routinely used in clinical care and where opportunities for further application exist.

Recent Findings The 2016 revision of the WHO classification of tumours of haematopoietic and lymphoid tissues increased the number of disease entities defined by, or whose diagnosis was strongly supported by, a specific genetic change. Increasingly combinations of mutations rather than individual lesions are being used to genomically classify heterogeneous disorders to inform prognosis and direct treatment. Furthermore, the role of different genetic aberrations as markers of measurable residual disease is being evaluated in clinical trials to allow intensification/de-intensification of treatment as appropriate and early detection of relapse. Summary Implementation of broader sequencing technologies such as whole exome/genome sequencing coupled with continuing developments in genomic technology to improve turn-around-times are likely to further reinforce the centrality of genomics in the management of haematological malignancies.
\end{abstract}

Keywords Haematological malignancies $\cdot$ Genomics $\cdot$ Cytogenetics $\cdot$ NGS $\cdot$ Prognosis $\cdot$ MRD

\section{Introduction}

Since Nowell and Hungerford discovered a recurrent abnormal chromosome in patients with chronic myeloid leukaemia (CML) in 1960, haematological malignancies have been at the forefront of cancer genomics and the related quest for personalised medicine [1]. Indeed, by way of introduction, CML (a clonal myeloproliferative disorder characterised by an

This article is part of the Topical Collection on Cancer Genomics

Angela Hamblin

angela.hamblin@ouh.nhs.uk

1 VUmc School of Medical Sciences, Vrije Universiteit, De Boelelaan 1117, 1118, 1081 HV Amsterdam, Netherlands

2 Department of Oncology, University of Oxford, Old Road Campus Research Building, Roosevelt Drive, Oxford OX3 7DQ, UK

3 Department of Laboratory Haematology, Oxford University Hospitals NHS Foundation Trust, John Radcliffe Hospital, Headley Way, Oxford OX3 9DU, UK

4 NIHR Oxford Biomedical Research Centre, John Radcliffe Hospital, Headley Way, Oxford University Hospitals NHS Foundation Trust, Oxford OX3 9DU, UK accumulation of mature granulocytic cells and their precursors) provides a paradigm of how genomic knowledge is used in both the diagnosis and management of haematological malignancies.

Upon advent of $\mathrm{G}$ banding, the abnormal chromosome was shown to be a translocation between chromosomes 9 and 22 $[\mathrm{t}(9 ; 22)]$; the Philadelphia $(\mathrm{Ph})$ chromosome. Further analysis showed this resulted in a $B C R-A B L 1$ fusion gene creating a constitutively active tyrosine kinase (TK) $[2,3]$. Subsequent in vitro and in vivo studies demonstrated $B C R-A B L 1$ is central to the pathogenesis of CML and activates an array of downstream signalling pathways resulting in uncontrolled cellular proliferation and survival $[4,5]$.

Detection of $B C R-A B L 1$ forms part of the diagnostic criteria of CML while detection of certain additional cytogenetic abnormalities (major route abnormalities) is associated with a worse prognosis and can influence initial treatment choice $[6 \bullet, 7]$. The discovery of a consistent molecular abnormality driving the pathogenesis of the disease provided a very attractive therapeutic target and the development of tyrosine kinase inhibitors (TKI) with significant activity against the BCR-ABL1 TK followed [8, 9]. The first TKI licensed for CML, imatinib, revolutionised management of the disorder: The 
International Randomized Study of Interferon and STI571 (IRIS]) demonstrated $73.8 \%$ versus $8.5 \%$ of patients treated with imatinib or interferon and cytarabine respectively achieved complete cytogenetic responses, i.e. absence of $\mathrm{t}(9 ; 22)$ using fluorescence in situ hybridisation (FISH) [10].

The centrality of the BCR-ABL1 fusion protein to the pathogenesis of CML means the presence of mRNA transcripts in peripheral blood leucocytes can be monitored using Quantitative Fluorescence-Polymerase Chain Reaction (QF-PCR) during treatment as a marker of measurable/minimal residual disease (MRD). This is now critical in the management of CML with International Standards allowing inter-lab comparison, and also informs the decision to stop TKI therapy [11•, 12]. In the event of primary or acquired resistance to a TKI, the $B C R-A B L 1$ transcript can be sequenced to detect mutations predicted to reduce the efficacy of specific TKIs and therefore direct treatment changes. The $B C R$ $A B L 1$ T315I mutation is associated with resistance to all licensed TKIs other than ponatinib, a third generation TKI $[13,14]$. Studies are now ongoing to identify very low level $B C R-A B L 1$ mutations prior to clinical evidence of TKI-resistance with the aim of earlier clinical intervention [15].

Therefore, CML in a single disease provides examples of how genomics is clinically used to inform diagnosis, prognosis, therapy response prediction and monitoring of disease burden. Although perhaps the most comprehensive example, CML is not alone within haematological malignancies in having genomics increasingly central to disease management: A combination of the frequent availability of both high-quality genomic material (obtainable from blood and bone marrow aspirate samples) and high throughput next generation sequencing (NGS) technologies has led to an explosion of genomic knowledge starting to filter through to clinical practice. This is illustrated by the prominence of genomics in the 2016 revision of the 'WHO classification of tumors of hematopoietic and lymphoid tissues' $[16-17 \cdot \bullet]$.

Although a systematic representation of the genomics of the 198 different disease entities described in the updated WHO classification is beyond the scope of this review, it will seek to discuss the more common practice-changing examples of the application of genomics to haematological malignancies as well as some potential developments on the horizon and remaining unanswered questions. Due to space constraints, discussion will be limited to somatic abnormalities. In order that the non-haematologist can orientate themselves around the haematological malignancies discussed, Fig. 1 provides a broad classification schema.

\section{Myeloid Disorders}

\section{Acute Myeloid Leukaemia}

Acute myeloid leukaemia (AML) is a clonal disorder characterised by expansion of primitive myeloid precursors (blasts) with failure of differentiation and associated bone marrow failure. Unlike CML where a single genetic abnormality defines the disease, in AML the genomic landscape is heterogeneous at both a cytogenetic and molecular level [18••, 19]. Although the diagnosis of AML is usually based on the combination of morphological and immunophenotype findings, recurrent cytogenetic and molecular abnormalities have been described with diagnostic, prognostic, monitoring and more recently predictive clinical implications. Some of these recurrent abnormalities are deemed to be sufficiently associated with a specific prognosis or management strategy that they are classified as distinct disease subtypes within the WHO guidance [17••].

More than 20 years of cytogenetic analysis (metaphase karyotyping) correlated with outcomes within clinical trials have allowed the prognostic significance of recurrent cytogenetic abnormalities to be determined [20]. Cytogenetic changes are separated into favourable, intermediate and poor risk groups [21•,22]. Approximately $40 \%$ of patients have a normal karyotype cytogenetically (deemed intermediate risk). Favourable changes include $\mathrm{t}(15 ; 17) P M L-R A R A, \mathrm{t}(8 ; 21)$ RUNXI-RUNXIT1 and inv(16)/t(16;16) CBFB-MYH11 while unfavourable abnormalities include inv(3)/t(3;3) GATA2MECOM, $\mathrm{t}(6 ; 9)$ DEK-NUP214, certain MLL rearrangements, del5, del5q, del7, del7q, del17, 17p abnormalities and complex karyotype ( $\geq 3$ abnormalities). All other patients are considered to be in the intermediate risk group.

The presence of $t(15 ; 17)$ correlates with the distinct morphological entity acute promyelocytic leukaemia (APML), characterised by an excess of promyelocytes and associated with a coagulopathy clinically. Identification of this abnormality warrants treatment using all trans retinoic acid (ATRA) either in combination with chemotherapy, or arsenic trioxide [23]. AML with $t(8 ; 21)$ or inv(16)/t $(16 ; 16)$, collectively known as core binding factor (CBF) leukaemia, appear to derive benefit from gemtuzumab ozogamicin in combination with chemotherapy, particularly in comparison with AML with unfavourable cytogenetics. Studies are now exploring whether intensification of the accompanying chemotherapy backbone improves survival $[24,25]$. Assuming a patient is otherwise suitable, in the event of unfavourable cytogenetics, a consolidative allogeneic haematopoietic stem cell transplant (HSCT) would normally be considered in first complete remission $[21,22,26]$.

In both APML and CBF-leukaemia, the disease-defining gene fusions are used for QF-PCR-based MRD monitoring. In APML early detection of incipient relapse is of particular 


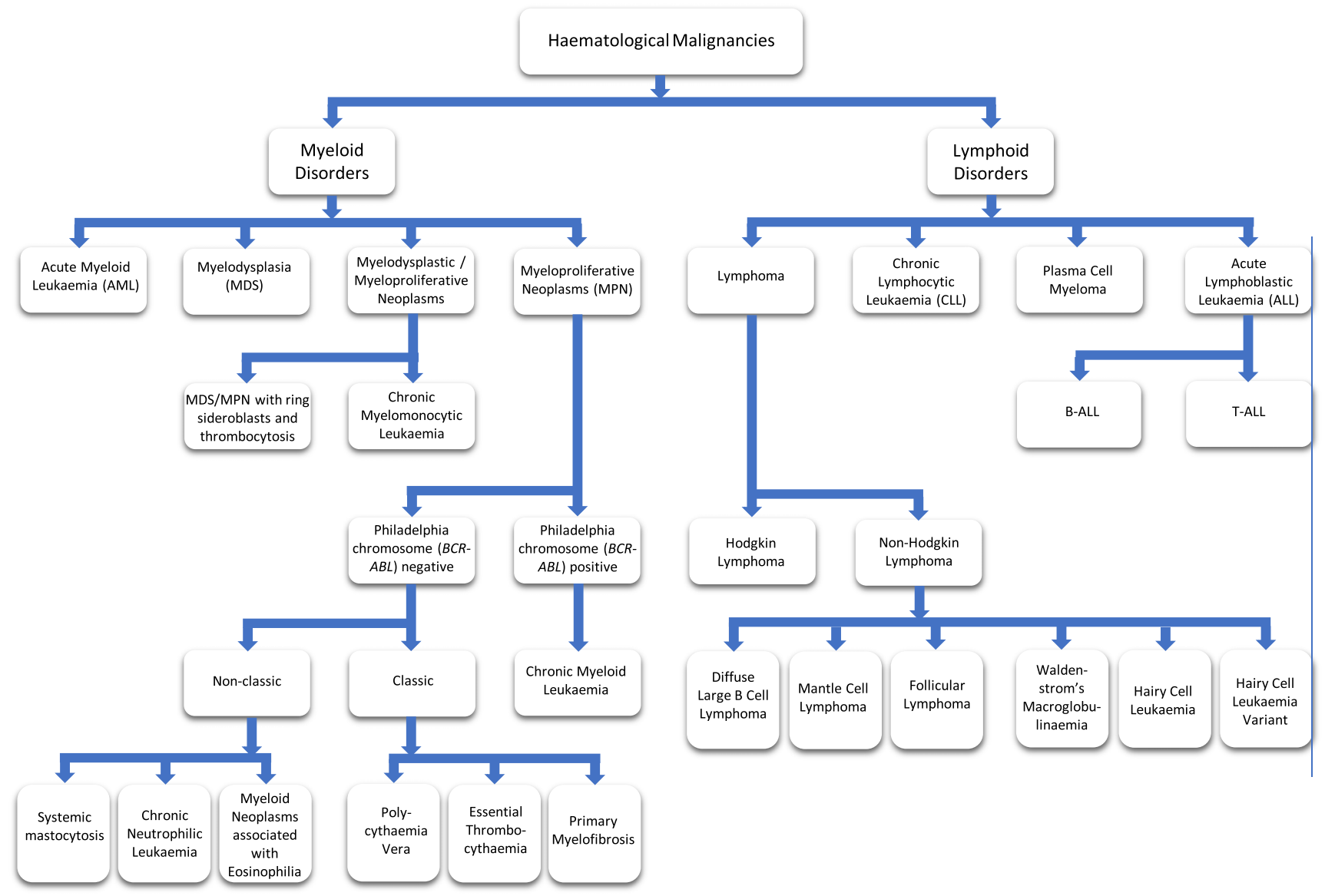

Fig. 1 Broad classification of haematological malignancies discussed in this review

importance owing to the frequently associated coagulopathy which can result in life-threatening haemorrhage [27]. In CBF-leukaemia, molecular response after induction is predictive of the risk of relapse; remission monitoring can allow further treatment prior to a full-blown morphological relapse and prolonged neutropenic period with the associated risk of infection [28].

Individual gene mutations, particularly in the context of a normal karyotype, can also affect prognosis and therefore management strategy, with some defining specific (provisional) subtypes of AML within the WHO classification [17]. An insertion within exon 12 of NPM1 destroying the nucleolar localisation signal at the $\mathrm{C}$ terminus or biallelic CEBPA mutations are associated with a better prognosis, and in the absence of other poor risk features, these patients would not normally have an allogeneic HSCT in first remission [29-31]. NPM1 mutant transcripts can also be used for MRD monitoring with the absence of the transcript in peripheral blood after the second cycle of induction chemotherapy being associated with a lower risk of relapse [32••].

In contrast the presence of a FLT3-ITD (removes autoinhibition of the tyrosine kinase) particularly with a high mutant: wild-type allele ratio is associated with a poor prognosis, as is the presence of mutations in ASXL1, RUNX1 or
TP53, all of which are recent additions into international guidelines containing screening recommendations [21, 33-37]. FLT3, being a tyrosine kinase, is an attractive target for TKIs, and a recent phase 3 trial of the multi-targeted kinase inhibitor midostaurin has shown improved overall survival (OS) and event free survival when given in combination with chemotherapy. This benefit was also seen in the context of activating mtuations within the tyrosine kinase domain (FLT3-TKD mutants), an abnormality whose effect on prognosis is less clear $[38 \cdot, 39]$.

However, even the limited selection of genomic abnormalities discussed above often does not occur in isolation, and it is necessary to try and group combinations of mutations into prognostic hierarchies. One such example is the work of Papaemmanuil et al. who used data obtained from cytogenetics, and a 111 gene-targeted sequencing panel to define 14 different genomic subgroups of AML based on segregation of genetic abnormalities [18$\bullet$ ]. Reassuringly this demonstrated many of the previously reported subtypes (see above) but in addition defined two new poor prognosis (mutations in chromatin and/or RNA-splicing regulators, and TP53 mutations and/or chromosomal aneuploidies) and one new good prognosis (IDH2 R172 mutant) categories. Other work investigating the ontogeny of AML suggests mutations in chromatin 
and/or RNA-splicing regulators are likely to be associated with a precedent myelodysplastic syndrome (MDS) which is not always documented clinically but is associated with a poorer prognosis [40].

More extensive sequencing approaches have revealed new potential drug targets: early trials of $I D H 1$ and $I D H 2$ inhibitors have returned promising results in the relapsed/refractory population where treatment options are usually limited [41, 42]. They also raise the potential of molecular MRD for all; however, studies have shown that the persistence of some mutations (those most frequently associated with clonal haematopoiesis of indeterminate prognosis [CHIP], i.e. ASXL1, DNMT3A, TET2) does not correlate with an increased risk of relapse, whilst others persist at variant allele frequencies which suggest they are present in morphologically normal cells [43•]. One final caution relating to choice of sequencing technology which has implications beyond AML is how to equate results from a high sensitivity technique such as whole genome sequencing (WGS) to a low sensitivity assay such as conventional metaphase karyotyping: what constitutes a complex karyotype with WGS? Further evaluation is required within clinical trials to generate data of equivalent robustness to that which underpins accepted management-informing genomic knowledge in AML.

\section{Myelodysplastic Syndromes}

Myelodysplastic syndromes (MDS) are a clinically heterogenous group of haematological malignancies characterised by ineffective haematopoiesis, peripheral blood cytopenias and a predisposition to AML. Recurrent cytogenetic abnormalities are reported in approximately $50 \%$ of patients with MDS and are associated with differential prognoses which can be incorporated into multifactorial prognostic scores [44-46]. The Revised International Prognostic Scoring System (IPSS-R) includes a refined cytogenetic classification containing additions such as discriminating between a complex karyotype with 3 or $>3$ abnormalities (poor and very poor risk respectively) and accommodating dual cytogenetic abnormalities [46].

Addition of FISH and high resolution single nucleotide polymorphism (SNP) array analyses can provide additional structural abnormality data allowing further reclassification. However, it should be noted that the IPSS-R used only metaphase karyotyping, and it is unclear whether the same clinical correlations will be apparent using higher resolution technology $[47,48]$. The most frequently occurring cytogenetic abnormality of $\operatorname{del}(5 q)$ is found in $\sim 15 \%$ of patients with MDS [49]. This is associated with a macrocytic anaemia often resulting in red blood cell (RBC) transfusion dependence. Treatment with the immunomodulatory agent lenalidomide can restore RBC-transfusion independence in $\sim 50 \%$ of patients [50]. Approximately $20 \%$ of patients with MDS with $\operatorname{del}(5 q)$ also harbour TP53 mutations either at diagnosis or which emerge during treatment and are associated with an increased risk of progression to AML [51, 52].

With the ready availability of NGS, attention has now turned to understanding molecular abnormalities in MDS. Progressively broader sequencing studies have demonstrated a molecularly heterogeneous genomic landscape with frequent mutations in genes involved in RNA splicing and epigenetic modifications (i.e. DNA methylation and histone modifications) $[53,54 \cdot, 55]$. Aside from there being a correlation between increasing numbers of driver mutations and worsening leukaemia-free survival, such studies have shown a strong genotype:phenotype correlation between somatically acquired mutations in the spliceosome constituent gene $S F 3 B 1$ and the presence of ring sideroblasts: Approximately $80 \%$ of patients with refractory anaemia with ring sideroblasts (RARS) and refractory cytopenia with multilineage dysplasia (RCMD) have an SF3B1 mutation [56]. SF3B1-mutated MDS typically has a more indolent course and better clinical outcome compared with other MDS subtypes. The presence of an $S F 3 B 1$ mutation also correlates with a response to the TGF $\beta$ superfamily inhibitor luspatercept in early phase clinical trials [57].

Work is ongoing to more systematically determine which gene mutations are associated with a favourable and unfavourable prognosis and how this can be combined with cytogenetics data into a comprehensive genetic risk model: One such model from the Mayo clinic identifies $S F 3 B 1$ versus TP53, RUNX1, U2AF1, ASXL1, EZH2 and SRSF2 mutations as favourable and unfavourable respectively on univariate analysis [58]. The impact of mutations on commonly employed treatments is also being evaluated. Mutations in TP53, JAK2 and the RAS pathway are associated with inferior survival post allogeneic HSCT (the only curative treatment for MDS) compared with patients without these abnormalities, although in the case of RAS pathway mutations use of an intensive conditioning regiment may ameliorate this risk [59•]. Identification of mutations associated with a poor prognosis when treated with conventional agents including chemotherapy has led to investigations of novel targeted agents. Examples include the use of the BCL2 inhibitor venetoclax in TP53-mutated disease and IDH1/2 inhibitors in IDH-mutated MDS [60].

In addition to providing prognostic information, the detection of a clonal cytogenetic or molecular marker can be useful diagnostically, particularly if there are potential alternative diagnoses or no excess of blasts morphologically. However, care must be taken in the interpretation of any molecular variant as whole exome sequencing (WES) studies of large numbers of individuals unaffected by haematological malignancies has shown agerelated acquisition of mutations in genes associated with haematological malignancies: CHIP. The presence of such 
mutations is associated with an increased risk of subsequent haematological malignancy development and cardiovascular disease $[61 \cdot, 62]$. Furthermore, the presence of such mutations, particularly in PPM1D, pre-autologous HSCT, is associated with an increased risk of secondary MDS/AML post-autograft [63•].

\section{Myeloproliferative Neoplasms}

Myeloproliferative neoplasms (MPN) are characterised by the overproduction of mature blood cells and are divided into $\mathrm{Ph}+$ and $\mathrm{Ph}-$ diseases. The $\mathrm{Ph}+$ disease entity is CML, the genetics of which is discussed in the introduction. Ph- MPN are a far more heterogeneous group of disorders which can be separated into classic and non-classic groups. Classic $\mathrm{Ph}-\mathrm{MPN}$ include polycythaemia vera (PV), essential thrombocythaemia (ET) and primary myelofibrosis (PMF) associated with increased erythroid activity, increased platelet numbers and bone marrow fibrosis respectively. The first driver mutation discovered in $\mathrm{Ph}-\mathrm{MPN}$ was JAK2 V617F with large scale sequencing studies showing its presence in $95 \% \mathrm{PV}$ and 50 $60 \%$ ET and PMF patients [64, 65]. In the majority of JAK2 V617F mutation-negative patients with PV an insertion/ deletion mutation can be found in JAK2 exon 12 [66].

A minority of patients with ET (3\%) and PMF (5\%) were found to have mutations of the thrombopoietin receptor $M P L$ $[65,67]$. In 2013, WES studies of patients with MPN which hitherto did not have a demonstrable driver mutation demonstrated most had an insertion/deletion mutation in CALR exon 9 resulting in loss of the protein's endoplasmic reticulum retention motif $[68,69]$. The driver mutations of classic $\mathrm{Ph}-$ MPN all ultimately activate the cytokine receptor/JAK2/ STAT pathway and its downstream effectors a fact exploited by the use of JAK $1 / 2$ inhibitors in the treatment of particularly PMF $[65,70]$. The essential role of these driver mutations in generating the MPN phenotype has led to their inclusion in disease-specific diagnostic criteria. In their absence, the presence of a variant in a gene recurrently mutated in myeloid disorders can be used as evidence of clonal haematopoiesis [17].

The presence of specific mutations (driver and non-driver) in MPNs is being used to refine prognosis: A high-molecular risk category of PMF has been defined by mutations in $A S X L 1, E Z H 2, I D H 1 / 2$ and SRSF2 and is associated with reduced survival and increased rate of transformation to AML [71]. Both high risk cytogenetic and molecular abnormalities are being combined with other laboratory and clinical parameters in PMF to produce enhanced, prognostic scoring systems such as MIPSS70+ Version 2.0 [72•]. Similarly, clinical, laboratory, cytogenetic and molecular mutation data has been combined to create a personalised outcome prediction tool for the different MPNs that may help identify those patients at unexpected high risk of an early death or transformation to AML who would potentially benefit from clinical trials of novel therapies [73••].

Among the non-classic $\mathrm{Ph}-$ MPNs, the identification of specific mutations can also have both diagnostic and therapeutic implications: Systemic mastocytosis (SM), characterised by organ dysfunction in association with the accumulation of abnormal mast cells, is almost always associated with an activating KIT D816 mutation which can be targeted by kinase inhibitors (e.g. midostaurin) [74, 75]. Chronic neutrophilic leukaemia is often associated with a mutation of CSF3R the nature of which (membrane proximal or cytoplasmic tailtruncating) influence whether the disease responds to TK or JAK inhibitors [76]. Similarly, myeloid neoplasms associated with eosinophilia are often associated with translocations of PDGFRA, PDGFRB, FGFR1 or PCM1-JAK2 with the identity of the translocation partners determining differential response to TK and JAK inhibitors [77].

A further group of myeloid disorders straddle the MDS and MPN diagnostic categories, i.e. MDS/MPN. The most common of these is chronic myelomonocytic leukaemia (CMML), characterised by a persistent blood monocytosis with accompanying morphological dysplasia. Although conventional karyotyping is often normal, targeted sequencing usually reveals mutations in one or more of TET2, SRSF 2 or ASXL1 [17]. The clinical phenotype and disease behaviour of CMML is heterogeneous, correlating with the variation in acquired genetic abnormalities: Progression towards AML is seen in association with the acquisition of new RAS mutations whereas a more dysplastic phenotype can occur with cooccurrence of traditional MDS mutations, e.g. of $U 2 A F 1$ or $S F 3 B 1$ [78]. In some MDS/MPN category disorders, the combined phenotype appears to reflect co-occurring mutations: In MDS/MPN with ring sideroblasts and thrombocytosis, both $S F 3 B 1$ and JAK2 mutations are frequently seen [79].

\section{Lymphoid Disorders}

\section{Acute Lymphoblastic Leukaemia}

Acute lymphoblastic leukaemia (ALL) is a clonal disorder characterised by expansion of primitive lymphoid precursors (blasts) and associated bone marrow failure. The diagnosis of ALL is usually made using morphological and immunophenotype information and further categorisation reflects antigen receptor rearrangement, i.e. B cell receptor (BCR) in B-ALL and T cell receptor (TCR) in T-ALL. The genomics of both subtypes are heterogeneous with more being known about that of B-ALL owing to its higher incidence. Although a broad range of both structural and small variant abnormalities have been described in ALL, currently structural aberrations are more frequently used for diagnostic, prognostic and predictive purposes in both paediatric and adult disease $[80,81]$. 
As seen with AML, decades of cytogenetic and FISH analysis have allowed identification of recurrent abnormalities with strong enough prognostic or management implications for them to be considered distinct disease subtypes within the WHO guidance [17, 82-84]. In B-ALL these include the good prognosis hyperdiploidy ( $>50$ chromosomes) and $\mathrm{t}(12 ; 21)$ ETV6-RUNX1, and poorer prognosis hypodiploidy $(<44$ chromosomes), $\mathrm{t}(9 ; 22) B C R-A B L 1, M L L$-rearrangement and iAMP21 (intrachromosomal amplification of chromosome 21) [80]. Identification of poorer prognosis cytogenetic abnormalities allows upfront treatment intensification or, in the case of detection of the $B C R-A B L 1$ translocation, addition of a TKI which can improve long-term outcomes [85, 86].

A recent refinement to the genomic classification of BALL followed gene expression profiling which revealed a group of patients with no risk-defining cytogenetic abnormalities had a similar expression profile to patients with a $B C R$ $A B L 1$ translocation, i.e. Ph-like/BCR-ABL1-like ALL [87]. Further investigations have shown most patients with this profile have kinase activating changes, e.g. translocations of $A B L 1, A B L 2, C R L F 2, C S F 1 R, E P O R, J A K 2, N T R K 3$, PDGFRB, PTK2B, TSLP or TYK2 or mutations of FLT3, $I L 7 R$ or $S H 2 B 3$. These have differential responses to available TKIs which can be used in combination with conventional chemotherapy [88•]. It is of note that the prevalence of the different subtypes of B-ALL varies with age; $M L L$-rearranged disease is seen $<12$ months, hyperdiploidy, and the ETV6RUNX1 translocation are more frequent in younger children while $\mathrm{Ph}+$ and $\mathrm{Ph}$-like ALL has a higher prevalence in adolescents and young adults [80]. The age-related distribution of genomic abnormalities is reflected in OS rates in different agegroups.

Sequencing studies in T-ALL have shown that although heterogeneous, genomic abnormalities largely correlate with the stage of maturation arrest of the blasts. Activation of the NOTCH1-signalling pathway, including activating mutations of NOTCH1 itself, is common to many cases of T-ALL. Frequent translocations of transcription factors, e.g. TAL1, TXL1, TXL3 or loss of cell cycle control loci such as $C D K N 2 A$ are also seen. Although some mutations are potentially targetable, practical implementation is problematic due to the need for evaluation within clinical trials despite the paucity of patients with any particular combination of mutations and the risk of secondary resistance; issues not unique to T-ALL [89].

Similar to myeloid malignancies, genomic abnormalities can be used for MRD monitoring. BCR-ABL1 transcripts are monitored in $\mathrm{Ph}+\mathrm{ALL}$ (as per CML), and there is the potential to monitor other chromosomal translocations if appropriately sensitive QF-PCR assays exist. However, most MRD performed exploits the clonal nature of the BCR or TCR rearrangement seen in ALL $[90,91]$. The unique VDJ and VJ rearrangements of the heavy and light chains respectively from the BCR (i.e. immunoglobulin [IG] genes)/TCR can be measured using QF-PCR post-treatment to detect MRD. The absence of MRD during treatment has been shown to correlate with a better prognosis and increasingly MRD negativity is being used to de-intensify treatment to try to minimise side effects $[92 \bullet \bullet, 93 \bullet]$.

\section{Lymphoma}

Lymphomas are clonal disorders arising from lymphocytes and constitute a heterogenous group of malignancies found in the lymph nodes, spleen, bone marrow, blood, and extranodal locations. They are categorised into Hodgkin and nonHodgkin types with the latter further divided by lymphocyte origin (T, B or NK cell). Their clinical course ranges from indolent to aggressive, and presentation varies including lymphadenopathy, splenomegaly and bone marrow failure. Genomic evaluation can be hampered by lack of fresh material as many do not involve blood or marrow. Technological improvements in the analysis of formalin-fixed paraffin-embedded material and more comprehensive collection of fresh tissue have allowed progress untangling the genomics of these tumours. The following are all non-Hodgkin lymphomas.

Diffuse large B cell lymphoma (DLBCL), the commonest adult lymphoma, is an aggressive subtype usually treated with combination chemo-immunotherapy (e.g. R-CHOP) to which the response can vary. FISH evaluation for $M Y C, B C L 2$ and/or $B C L 6$ rearrangements highlights a conventionally poor risk group (double/triple hit) who tend to inferior outcomes with this approach [94]. To date, there is no consensus as to appropriate treatment intensification/modification for this group, not least because of inconsistencies in outcomes in small retrospective case series. Emerging data demonstrating the importance of the translocation partner identity may explain some of this variation and also plan for future trials: poor prognosis is mostly limited to patients with double/triple hit with a MYC-IG gene partner translocation [95•].

Gene expression profiling (GEP) demonstrated two distinct subtypes of DLBCL with profiles similar to activated - or germinal centre - B cells (ABC v GCB) [96]. This division was deemed significant as patients with ABC-type often appear to have a worse outcome with standard chemoimmunotherapy treatment [97]. DNA sequencing showed that although DLBCL is genomically heterogeneous, there is some correlation between GEP and mutation type, i.e. ABC and GCB types have activating mutations in signalling pathways (e.g. MYD88, CD79B) and epigenetic modifiers (e.g. EZH2) respectively $[98,99]$.

Further studies have shown associations between specific mutations and site of disease: primary CNS and testicular DLBCL are associated with MYD88 L265P mutations while primary mediastinal B cell lymphoma has an over- 
representation of PTPN1 mutations [100, 101]. More recently sequencing studies have attempted to use multiple genomic abnormalities to classify DLBCL: Work by Staudt using an iterative approach generated an algorithm classifying $\sim 50 \%$ of cases into four distinct genomic categories which had implications for both the predicted origin of the DLBCL and utility of potential targeted therapies, e.g. Bruton's tyrosine kinase (BTK) inhibitors [102]. A similar approach by Shipp has generated a more comprehensive classifier able to assign over $95 \%$ of cases into one of five separate genomic categories. This includes the identification of a lower-risk ABC-type and poorer prognostic GCB-type which may explain some of the inconsistencies seen in different data series in patient outcomes [103••].

Owing to its B cell origin, DLBCLs have a clonal BCR (similar to B-ALL) which has the potential for use in noninvasive MRD detection. Unlike leukaemias, DLBCL cells are seldom found in the blood and marrow, meaning it is necessary to detect circulating tumour DNA shed into the plasma. Studies have shown tumour-associated VDJ/VJ rearrangements can be detected using QF-PCR of plasma DNA with reemergence of MRD being associated with subsequent relapse. Clinically it is relevant that MRD positivity predates radiologically detectable disease by a median 3-5 months [104].

In contrast to DLBCL, follicular lymphoma (FL) is a lowgrade B cell lymphoma associated with a $\mathrm{t}(14 ; 18)$ IGH-BCL2 translocation in $\sim 90 \%$ cases [105]. Extensive sequencing reveals it too has a heterogeneous genomic landscape both between separate patients and different locations of disease in an individual patient (evidence of subclones) [106, 107]. A proportion of patients (30-40\%) undergo transformation from FL to DLBCL, and sequencing of longitudinal samples demonstrates most transformed-FL arise from divergent evolution from a common precursor rather than direct linear evolution from the FL [108]. Attempts have been made to incorporate genomic information from NGS panels into clinical prognostic scoring systems (e.g. M7FLIPI) although, as yet, these are not widely used in clinical practice [109]. Such panels also have the potential to identify targetable mutations, e.g. activating $E Z H 2$ mutations [110].

Although with the exception of FISH testing, most of the data analysis described for DLBCL, and FL remains in the research/clinical trial sphere, genetic testing is increasingly being applied to routine lymphoma diagnostics/management: Mantle cell lymphoma (MCL), an intermediate grade malignancy, is associated with $\mathrm{t}(11 ; 14)$ IGH-CCND1 in $~ 95 \%$ of cases (with the remainder likely associated with translocations of $C C N D 2$ or $C C N D 3$ ) which forms part of the diagnostic algorithm [111, 112]. Demonstration of a TP53 mutation in MCL suggests patient will have a poor response to intensive chemoimmunotherapy followed by consolidative autologous
HSCT opening the way for alternative innovative treatment approaches [113].

Waldenstrom's macroglobulinaemia (WM), a low-grade lymphoma associated with secretion of a monoclonal $\operatorname{IgM}$ paraprotein, is associated in $>90 \%$ cases with a MYD 88 L265P mutation which can be used to differentiate the malignancy from its mimics [114]. Trial data shows that patients with MYD88-mutated WM have a better clinical response to the BTK-inhibitor ibrutinib than MYD 88 wild-type WM, while co-occurrence of a truncating mutation in $C X C R 4$ exon 2 attenuates that response [115]. The presence of the $B R A F$ $\mathrm{V} 600 \mathrm{E}$ mutation can be used to assist in the diagnosis of hairy cell leukaemia and can also be targeted by specific inhibitors (e.g. vemurafenib) in patients not responding to conventional management $[116,117]$. Similarly, although not pathognomonic, the presence of a $M A P 2 K 1$ mutation can assist in the diagnosis of hairy cell leukaemia variant [118].

Mutational analysis is also starting to be of clinical utility in the rarer T cell lymphomas given these can often be challenging histologically to differentiate from reactive $\mathrm{T}$ cells in the context of infection or an autoimmune reaction. Demonstration of mutations such as RHOA, TET2 or STAT3 can support a malignant diagnosis although it should be noted there is some promiscuity of mutations across subtypes [119, 120].

\section{Chronic Lymphocytic Leukaemia}

Chronic lymphocytic leukaemia (CLL) is a clonal disorder with a heterogeneous clinical course associated with progressive accumulation of mature B lymphocytes in the lymph nodes, spleen and bone marrow which can result in bone marrow failure. Similar to other haematological malignancies, the earliest prognostic abnormalities detected were cytogenetic: $\operatorname{del}(17 p) / \operatorname{del}(11 q)$ and $\operatorname{del}(13 q)$ were associated with shorter and longer OS rates respectively [121]. More recently, a complex karyotype (defined as $\geq$ 3 cytogenetic abnormalities in a single clone) has been shown to be associated with a poor prognosis with those patients with unbalanced chromosomal rearrangements having the worst prognosis [122]. However, technical difficulties with the culture of CLL cells means failure rates for conventional karyotyping are high and alternative technologies such as WGS may be required.

Owing to the vast difference in clinical outcomes of apparently similar diseases, great effort was put into defining the disease genetically: It was discovered that CLL can be divided into two similar-sized cohorts on the basis of whether the immunoglobulin heavy chain variable region sequence (IgHV) has undergone somatic hypermutation (physiological part of antibody affinity maturation in the lymph node) [123]. Patients with IgHV hypermutation have a better OS compared to those 
Table 1 Clinical utility of genomic abnormalities in different myeloid conditions

\begin{tabular}{|c|c|c|c|c|}
\hline $\begin{array}{l}\text { Haematological } \\
\text { malignancy }\end{array}$ & Genomic variant & $\begin{array}{l}\text { Current } \\
\text { technique(s) for } \\
\text { detection* }\end{array}$ & Clinical utility & Reference(s) \\
\hline $\begin{array}{l}\text { Chronic myeloid } \\
\text { leukaemia }\end{array}$ & $\mathrm{t}(9 ; 22)[\mathrm{Ph}$ chromosome $] B C R-A B L 1$ & $\begin{array}{l}\text { Karyotype; } \\
\text { FISH; } \\
\text { RT-PCR }\end{array}$ & Diagnosis; Targeted treatment (TKI) & {$[1-5,8-10]$} \\
\hline $\begin{array}{l}\text { Chronic myeloid } \\
\text { leukaemia }\end{array}$ & second $\mathrm{Ph}$ chromosome, $+8, \mathrm{i}(17 \mathrm{q}),+19$ & Karyotype; FISH & $\begin{array}{l}\text { Prognosis [poor] (major route } \\
\text { abnormalities) }\end{array}$ & {$[6 \bullet, 7]$} \\
\hline $\begin{array}{l}\text { Chronic myeloid } \\
\text { leukaemia }\end{array}$ & $B C R-A B L 1$ & QF-PCR & Disease response; MRD & {$[11 \bullet, 12]$} \\
\hline $\begin{array}{l}\text { Chronic myeloid } \\
\text { leukaemia }\end{array}$ & $B C R-A B L 1$ TKD mutations & $\begin{array}{l}\text { Nested PCR and } \\
\text { SS; NGS }\end{array}$ & TKI response prediction/choice & {$[13-15]$} \\
\hline $\begin{array}{l}\text { Acute myeloid } \\
\text { leukaemia }\end{array}$ & $\begin{array}{l}\mathrm{t}(15 ; 17) P M L-R A R A, \mathrm{t}(8 ; 21) \text { RUNXI-RUNXIT1, } \\
\text { inv(16)/t(16;16) CBFB-MYH11, inv }(3) / \mathrm{t}(3 ; 3) \\
\text { GATA2-MECOM, } \mathrm{t}(6 ; 9) D E K-N U P 214, \text { certain } \\
\text { MLL rearrangements, del5, del5q, del7, del7q, } \\
\text { del17, 17p abnormalities and complex } \\
\text { karyotype ( } \geq 3 \text { abnormalities) }\end{array}$ & Karyotype; FISH & $\begin{array}{l}\text { Prognosis [depends on abnormality]; } \\
\text { Informs intensity of treatment and need } \\
\text { for/timing of allogeneic HSCT }\end{array}$ & $\begin{array}{l}{[20,21 \cdot, 22,} \\
26]\end{array}$ \\
\hline $\begin{array}{l}\text { Acute } \\
\text { promyelocytic } \\
\text { leukaemia }\end{array}$ & $\mathrm{t}(15 ; 17) P M L-R A R A$ & $\begin{array}{l}\text { Karyotype; } \\
\text { FISH; } \\
\text { RT-PCR }\end{array}$ & $\begin{array}{l}\text { Diagnosis; Treatment choice, i.e. ATRA + } \\
\text { chemotherapy or arsenic trioxide }\end{array}$ & {$[23]$} \\
\hline $\begin{array}{l}\text { Acute } \\
\text { promyelocytic } \\
\text { leukaemia }\end{array}$ & $P M L-R A R A$ & QF-PCR & Disease response; MRD & {$[27]$} \\
\hline $\begin{array}{l}\text { Acute myeloid } \\
\text { leukaemia }\end{array}$ & $\begin{array}{l}\mathrm{t}(8 ; 21) \text { RUNX1-RUNX1T1, inv }(16) / \mathrm{t}(16 ; 16) \\
\quad \text { CBFB-MYH11 }\end{array}$ & $\begin{array}{l}\text { Karyotype; } \\
\text { FISH; } \\
\text { RT-PCR }\end{array}$ & $\begin{array}{l}\text { Diagnosis; Treatment choice i.e. } \\
\text { gemtuzumab ozogamicin }+ \\
\text { chemotherapy }\end{array}$ & {$[24,25]$} \\
\hline $\begin{array}{l}\text { Acute myeloid } \\
\text { leukaemia }\end{array}$ & RUNX1-RUNX1T1, CBFB-MYH11 & QF-PCR & Disease response; MRD & {$[28]$} \\
\hline $\begin{array}{l}\text { Acute myeloid } \\
\text { leukaemia }\end{array}$ & NPM1 exon 12 insertion & $\begin{array}{l}\text { FA; HRM; NGS; } \\
\text { (SS) }\end{array}$ & $\begin{array}{l}\text { Prognosis [good]; Informs need for/timing } \\
\text { of allogeneic HSCT }\end{array}$ & {$[29-31]$} \\
\hline $\begin{array}{l}\text { Acute myeloid } \\
\text { leukaemia }\end{array}$ & NPM1 exon 12 insertion & QF-PCR & Disease response; MRD & {$[32 \bullet \bullet]$} \\
\hline $\begin{array}{l}\text { Acute myeloid } \\
\text { leukaemia }\end{array}$ & FLT3 mutation (ITD or TKD mutation) & FA; NGS; (SS) & $\begin{array}{l}\text { Prognosis [poor]; Informs need for/timing } \\
\text { of allogeneic HSCT }\end{array}$ & {$[33,34]$} \\
\hline $\begin{array}{l}\text { Acute myeloid } \\
\text { leukaemia }\end{array}$ & FLT3 mutation (ITD or TKD mutation) & FA; NGS; (SS) & Targeted treatment $(\mathrm{TKI})$ & {$[38 \cdot, 39]$} \\
\hline $\begin{array}{l}\text { Acute myeloid } \\
\text { leukaemia }\end{array}$ & ASXL1, RUNX1, TP53 mutations & NGS & $\begin{array}{l}\text { Prognosis [poor]; Informs intensity of } \\
\text { treatment }\end{array}$ & {$[21 \cdot, 33-37]$} \\
\hline $\begin{array}{l}\text { Acute myeloid } \\
\text { leukaemia }\end{array}$ & $\begin{array}{l}\text { Multiple genetic abnormalities (structural and } \\
\text { small variant) }\end{array}$ & $\begin{array}{l}\text { Karyotype; } \\
\text { FISH; NGS }\end{array}$ & $\begin{array}{l}\text { Diagnosis; Prognosis [depends on } \\
\text { abnormality]; Informs intensity of } \\
\text { treatment }\end{array}$ & {$[18 \bullet \bullet, 40]$} \\
\hline $\begin{array}{l}\text { Acute myeloid } \\
\text { leukaemia }\end{array}$ & $I D H 1, I D H 2$ mutations & $\begin{array}{l}\text { Pyrosequencing; } \\
\text { NGS; (SS) }\end{array}$ & $\begin{array}{l}\text { Targeted treatment (IDH1 or } I D H 2 \\
\text { inhibitors) }\end{array}$ & {$[41,42]$} \\
\hline $\begin{array}{l}\text { Acute myeloid } \\
\text { leukaemia }\end{array}$ & Multiple small variants & NGS & Disease response; MRD & {$[43 \bullet]$} \\
\hline $\begin{array}{l}\text { Myelodysplastic } \\
\text { syndromes }\end{array}$ & $\begin{array}{l}- \text { Y, del }(11 \mathrm{q}), \text { normal, del }(5 \mathrm{q}), \operatorname{del}(12 \mathrm{p}), \operatorname{del}(20 \mathrm{q}) \\
\text { double including del }(5 \mathrm{q}), \operatorname{del}(7 \mathrm{q}),+8,+19, \\
\text { i( } 17 \mathrm{q}), \text { any other single or double independent } \\
\text { clones, }-7, \operatorname{inv}(3) / \mathrm{t}(3 \mathrm{q}) / \operatorname{del}(3 \mathrm{q}), \text { double } \\
\text { including }-7 / \operatorname{del}(7 \mathrm{q}), \text { complex: } 3 \text { abnormalities, } \\
\text { complex: }>3 \text { abnormalities }\end{array}$ & Karyotype; FISH & $\begin{array}{l}\text { Diagnosis; Prognosis [depends on } \\
\text { abnormality]; informs intensity of } \\
\text { treatment and need for/timing of } \\
\text { allogeneic HSCT }\end{array}$ & {$[44-46]$} \\
\hline $\begin{array}{l}\text { Myelodysplastic } \\
\text { syndromes }\end{array}$ & $\operatorname{del}(5 q)$ & Karyotype; FISH & Diagnosis; Treatment (lenalidomide) & {$[49,50]$} \\
\hline $\begin{array}{l}\text { Myelodysplastic } \\
\text { syndromes }\end{array}$ & TP53 mutations (in context of $\operatorname{del}(5 \mathrm{q})$ ) & NGS; (SS) & $\begin{array}{l}\text { Prognosis [poor]; Informs intensity of } \\
\text { treatment and need for/timing of } \\
\text { allogeneic HSCT }\end{array}$ & {$[51,52]$} \\
\hline $\begin{array}{l}\text { Myelodysplastic } \\
\text { syndromes }\end{array}$ & SF3B1 mutations & NGS; (SS) & $\begin{array}{l}\text { Prognosis [good]; Informs intensity of } \\
\text { treatment; Potentially informs treatment } \\
\text { (TGF } \beta \text { superfamily inhibitors) }\end{array}$ & {$[56,57]$} \\
\hline $\begin{array}{l}\text { Myelodysplastic } \\
\text { syndromes }\end{array}$ & $\begin{array}{l}\text { Multiple genetic abnormalities (structural and } \\
\text { small variant) }\end{array}$ & $\begin{array}{l}\text { Karyotype; } \\
\text { FISH; NGS }\end{array}$ & $\begin{array}{l}\text { Diagnosis; Prognosis [depends on } \\
\text { abnormality]; Informs intensity/choice }\end{array}$ & {$[58-60]$} \\
\hline
\end{tabular}


Table 1 (continued)

\begin{tabular}{|c|c|c|c|c|}
\hline $\begin{array}{l}\text { Haematological } \\
\text { malignancy }\end{array}$ & Genomic variant & $\begin{array}{l}\text { Current } \\
\text { technique(s) for } \\
\text { detection* }\end{array}$ & Clinical utility & Reference(s) \\
\hline & & & $\begin{array}{l}\text { of treatment and need for/timing of } \\
\text { allogeneic HSCT }\end{array}$ & \\
\hline $\begin{array}{l}\text { Myeloproliferative } \\
\text { Neoplasms } \\
\text { (classic } \mathrm{Ph}^{-} \text {) }\end{array}$ & $\begin{array}{l}J A K 2 \text { V617F, JAK2 exon 12, CALR exon 9, MPL } \\
\text { mutations }\end{array}$ & $\begin{array}{l}\text { QF-PCR; HRM; } \\
\text { NGS }\end{array}$ & Diagnosis & [64-69] \\
\hline $\begin{array}{l}\text { Myeloproliferative } \\
\text { neoplasms } \\
\text { (classic } \mathrm{Ph}^{-} \text {) }\end{array}$ & $\begin{array}{l}J A K 2 \text { V617F, JAK2 exon } 12, C A L R \text { exon } 9, M P L \\
\text { mutations, i.e. resulting in activation of cytokine } \\
\text { receptor/JAK2/STAT pathway }\end{array}$ & $\begin{array}{l}\text { QF-PCR; HRM; } \\
\text { NGS }\end{array}$ & JAK $1 / 2$ inhibitors & {$[65,70]$} \\
\hline $\begin{array}{l}\text { Primary } \\
\text { myelofibrosis }\end{array}$ & $A S X L 1, E Z H 2, I D H 1 / 2$ and $S R S F 2$ mutations & NGS; & $\begin{array}{l}\text { Prognosis [poor]; Helps inform } \\
\text { choice/timing of allogeneic HSCT }\end{array}$ & {$[71]$} \\
\hline $\begin{array}{l}\text { Primary } \\
\text { myelofibrosis }\end{array}$ & $\begin{array}{l}\text { Multiple genetic abnormalities (structural and } \\
\text { small variant) }\end{array}$ & $\begin{array}{l}\text { Karyotype; } \\
\text { FISH; NGS }\end{array}$ & $\begin{array}{l}\text { Prognosis [depends on abnormality]; Helps } \\
\text { inform choice/timing of allogeneic } \\
\text { HSCT }\end{array}$ & {$[72 \bullet]$} \\
\hline $\begin{array}{l}\text { Myeloproliferative } \\
\text { neoplasms } \\
\text { (classic } \mathrm{Ph}^{-} \text {) }\end{array}$ & $\begin{array}{l}\text { Multiple genetic abnormalities (structural \& small } \\
\text { variant) }\end{array}$ & $\begin{array}{l}\text { Karyotype; } \\
\text { FISH; NGS }\end{array}$ & $\begin{array}{l}\text { Prognosis [depends on abnormality]; Helps } \\
\text { inform choice/timing of treatment } \\
\text { including consideration of novel } \\
\text { therapies }\end{array}$ & {$[73]$} \\
\hline $\begin{array}{l}\text { Systemic } \\
\text { Mastocytosis }\end{array}$ & KIT D816V (and other) mutations & NGS; ddPCR & Diagnosis; Targeted treatment (TKI) & {$[74-75]$} \\
\hline $\begin{array}{l}\text { Chronic } \\
\quad \text { Neutrophilic } \\
\text { Leukaemia }\end{array}$ & CSF3R mutations & NGS; (SS) & $\begin{array}{l}\text { Diagnosis; Targeted treatment (TKI or JAK } \\
\text { inhibitors) }\end{array}$ & {$[76]$} \\
\hline $\begin{array}{l}\text { Myeloid } \\
\text { neoplasms } \\
\text { associated with } \\
\text { eosinophilia }\end{array}$ & $\begin{array}{l}\text { PDGFRA, PDGFRB, FGFR1 rearrangements, } \\
\quad \text { PCM1-JAK2 }\end{array}$ & $\begin{array}{l}\text { Karyotype; } \\
\text { FISH; } \\
\text { RT-PCR }\end{array}$ & $\begin{array}{l}\text { Diagnosis; Targeted treatment (TKI or JAK } \\
\text { inhibitors) }\end{array}$ & {$[77]$} \\
\hline
\end{tabular}

*The techniques indicated represent the commonest ways of delivering testing in routine practice. However, other techniques are available, e.g. microarray in place of karyotyping, amplification refractory mutation system [ARMS] PCR for mutation detection. Although SS can detect many similar small variants to NGS, its sensitivity is far lower (hence its placement in brackets in many instances)

TKI tyrosine kinase inhibitor, MRD minimal/measurable residual disease, HSCT haematopoietic stem cell transplant, ATRA all trans retinoic acid

$F I S H$ fluorescence in situ hybridisation; $R T-P C R$ reverse-transcriptase polymerase chain reaction, $Q F-P C R$ quantitative fluorescence polymerase chain reaction, $P C R$ polymerase chain reaction, $S S$ Sanger sequencing, $N G S$ next generation sequencing, $F A$ fragment analysis, $H R M$ high resolution melting analysis, $d d P C R$ digital droplet polymerase chain reaction

with unmutated IgHV and long-term follow-up suggests that some of these patients may even be cured with firstline chemo-immunotherapy (FCR) $[124,125]$. The consistency of the effect of IgHV mutation status on prognosis has led to its incorporation in the CLL international prognostic index [126].

Disruption of TP53 either via deletion, mutation or both has also been shown to be a poor prognostic factor in CLL associated with primary refractoriness to chemo-immunotherapy, even if the aberration is in a small subclone [127, 128]. In such cases, small molecular inhibitors targeting BTK, PI3K or BCL2 are preferred [129]. Deep sequencing using NGS panels can detect subclonal mutations, which may ultimately confer resistance to these inhibitors, many months before relapse, e.g. mutations in BTK and PLCG2 can result in resistance to BTK inhibitors [130]. Ongoing sequencing studies are continuing to identify driver mutations affecting a range of cellular processes which have the potential to direct therapy [131].

\section{Plasma Cell Myeloma}

Plasma cell myeloma is defined by the accumulation of clonal plasma cells in the bone marrow resulting in end organ damage such as bone marrow failure, destructive bone lesions, hypercalcaemia or renal impairment. It too is associated with both a variable clinical outcome and genomic heterogeneity. Metaphase FISH performed in the context of clinical trials has revealed a number of poor prognosis aberrations defining a cytogenetically high-risk group of patients. Although most trials agree del $(17 \mathrm{p}), \mathrm{t}(4 ; 14)$ and $\mathrm{t}(14 ; 16)$ are associated with a poor outcome, different trials have reached varying conclusions about the significance of $t(14 ; 20)$, non-hyperdiploidy, $\operatorname{del}(1 p)$ and gain(1q), and it is likely that some trial therapies may mitigate some of the poor prognosis otherwise seen [132, 133]. Identification of high-risk patients allows for upfront intensification of treatment and enrolment in clinical trials evaluating novel therapies [134]. It should be noted that the 
Table 2 Clinical utility of genomic abnormalities in different lymphoid conditions

\begin{tabular}{|c|c|c|c|c|}
\hline $\begin{array}{l}\text { Haematological } \\
\text { malignancy }\end{array}$ & Genomic variant & $\begin{array}{l}\text { Current } \\
\text { technique(s) for } \\
\text { detection* }\end{array}$ & Clinical utility & Reference(s) \\
\hline $\begin{array}{l}\text { B-cell acute } \\
\text { lymphoblastic } \\
\text { leukaemia }\end{array}$ & $\begin{array}{c}\text { Hyperdiploidy, } \mathrm{t}(12 ; 21) \text { ETV6-RUNX1, } \\
\text { hypodiploidy, t(9;22) BCR-ABL1, } \\
\text { MLL-rearrangement and iAMP21 }\end{array}$ & $\begin{array}{l}\text { Karyotype; } \\
\text { FISH }\end{array}$ & $\begin{array}{l}\text { Prognosis [depends on abnormality]; } \\
\text { Informs intensity of treatment and } \\
\text { need for/timing of allogeneic HSCT }\end{array}$ & {$[80-85]$} \\
\hline $\begin{array}{l}\text { B-cell acute } \\
\text { lymphoblastic } \\
\text { leukaemia }\end{array}$ & $\mathrm{t}(9 ; 22) B C R-A B L 1$ & $\begin{array}{l}\text { Karyotype; } \\
\text { FISH }\end{array}$ & Targeted treatment (TKI) & {$[86]$} \\
\hline $\begin{array}{l}\text { B-cell acute } \\
\text { lymphoblastic } \\
\text { leukaemia }\end{array}$ & $\begin{array}{l}A B L 1, A B L 2, C R L F 2, C S F 1 R, E P O R, J A K 2, \\
\quad N T R K 3, P D G F R B, P T K 2 B, T S L P, T Y K 2 \\
\text { translocations or mutations of } F L T 3, I L 7 R \text { or } \\
\quad S H 2 B 3\end{array}$ & $\begin{array}{l}\text { FISH; RT-PCR; } \\
\text { other RNA } \\
\text { sequencing; } \\
\text { NGS }\end{array}$ & $\begin{array}{l}\text { Prognosis [conventionally poor]; } \\
\text { Targeted treatment (TKI) }\end{array}$ & {$[87,88 \bullet]$} \\
\hline $\begin{array}{l}\text { B-cell acute } \\
\text { lymphoblastic } \\
\text { leukaemia }\end{array}$ & $\mathrm{t}(9 ; 22) B C R-A B L 1$ & QF-PCR & Disease response; MRD & {$[92 \cdot]$} \\
\hline $\begin{array}{l}\text { Acute } \\
\text { lymphoblastic } \\
\text { leukaemia }\end{array}$ & $\begin{array}{l}\text { Immunoglobulin gene/T cell receptor gene } \\
\text { rearrangements }\end{array}$ & QF-PCR & Disease response; MRD & {$[90,91]$} \\
\hline $\begin{array}{l}\text { Diffuse large B-cell } \\
\text { lymphoma }\end{array}$ & $M Y C$ and $B C L 2$ and/or $B C L 6$ rearrangements & FISH & Prognosis [poor] & {$[94,95 \bullet]$} \\
\hline $\begin{array}{l}\text { Diffuse large B-cell } \\
\text { lymphoma }\end{array}$ & Multiple small variants & NGS & $\begin{array}{l}\text { Diagnosis (activated B-cell versus } \\
\text { germinal centre B cell type); } \\
\text { Prognosis [depends on abnormality] }\end{array}$ & {$[98,99]$} \\
\hline $\begin{array}{l}\text { Diffuse large B-cell } \\
\text { lymphoma }\end{array}$ & $\begin{array}{l}\text { Multiple genetic abnormalities (structural and small } \\
\text { variant) }\end{array}$ & $\begin{array}{l}\text { Karyotype; } \\
\text { FISH; NGS }\end{array}$ & $\begin{array}{l}\text { Prognosis [depends on abnormality]; } \\
\text { Potential to inform treatment options }\end{array}$ & {$[102,103 \bullet \bullet]$} \\
\hline $\begin{array}{l}\text { Diffuse large B-cell } \\
\text { lymphoma }\end{array}$ & Immunoglobulin gene rearrangement & QF-PCR & Disease response; MRD & {$[104]$} \\
\hline $\begin{array}{l}\text { Primary } \\
\text { CNS/Testicular } \\
\text { diffuse large } \\
\text { B-cell lymphoma }\end{array}$ & MYD88 L265P mutation & $\begin{array}{l}\text { QF-PCR; NGS; } \\
\quad \text { (SS) }\end{array}$ & Diagnosis & {$[100]$} \\
\hline $\begin{array}{l}\text { Primary mediastinal } \\
\text { B-cell lymphoma }\end{array}$ & PTPN1 mutations & NGS; (SS) & Diagnosis & {$[101]$} \\
\hline $\begin{array}{l}\text { Follicular } \\
\text { lymphoma }\end{array}$ & $\mathrm{t}(14 ; 18) \mathrm{IGH}-B C L 2$ & FISH & Diagnosis & {$[105]$} \\
\hline $\begin{array}{l}\text { Follicular } \\
\text { lymphoma }\end{array}$ & Multiple small variants & NGS & $\begin{array}{l}\text { Prognosis [depends on abnormality]; } \\
\text { Helps inform choice/timing of } \\
\text { treatment }\end{array}$ & [109] \\
\hline $\begin{array}{l}\text { Follicular } \\
\text { lymphoma }\end{array}$ & Activating $E Z H 2$ mutations & NGS; (SS) & Targeted treatment (EZH2 inhibitors) & {$[110]$} \\
\hline $\begin{array}{l}\text { Mantle cell } \\
\text { lymphoma }\end{array}$ & $\begin{array}{l}(11 ; 14) \mathrm{IGH}-C C N D 1, C C N D 2 / C C N D 3 \\
\quad \text { rearrangements }\end{array}$ & $\begin{array}{l}\text { FISH; RT-PCR; } \\
\text { other RNA } \\
\text { sequencing; } \\
\text { NGS }\end{array}$ & Diagnosis & {$[111-112]$} \\
\hline $\begin{array}{l}\text { Mantle cell } \\
\text { lymphoma }\end{array}$ & TP53 mutations & NGS; (SS) & $\begin{array}{l}\text { Prognosis [poor]; Helps inform choice } \\
\text { of treatment including consideration } \\
\text { of novel therapies }\end{array}$ & [113] \\
\hline $\begin{array}{l}\text { Waldenstrom's } \\
\text { macroglobulinae- } \\
\text { mia }\end{array}$ & MYD88 L265P mutation & $\begin{array}{l}\text { QF-PCR; NGS; } \\
\quad \text { (SS) }\end{array}$ & $\begin{array}{l}\text { Diagnosis; Targeted treatment (BTK } \\
\text { inhibitor) }\end{array}$ & [114] \\
\hline $\begin{array}{l}\text { Waldenstrom's } \\
\text { macroglobulinae- } \\
\text { mia }\end{array}$ & CXCR4 exon 2 truncating mutations & NGS; (SS) & $\begin{array}{l}\text { Predicted response to targeted treatment } \\
\text { (BTK inhibitor) }\end{array}$ & {$[115]$} \\
\hline Hairy cell leukaemia & $B R A F \mathrm{~V} 600 \mathrm{E}$ & QF-PCR; NGS & $\begin{array}{l}\text { Diagnosis; Targeted treatment (BRAF } \\
\text { inhibitor) }\end{array}$ & {$[116-117]$} \\
\hline $\begin{array}{l}\text { Hairy cell leukaemia } \\
\text { variant }\end{array}$ & MAP2K1 mutations & NGS; (SS) & Diagnosis & {$[118]$} \\
\hline T cell lymphoma & RHOA, TET2, STAT3 and other mutations & NGS; & Diagnosis & {$[119-120]$} \\
\hline $\begin{array}{l}\text { Chronic } \\
\text { lymphocytic } \\
\text { leukaemia }\end{array}$ & $\operatorname{del}(17 p) / \operatorname{del}(11 q)$ and $\operatorname{del}(13 q)$; complex karyotype & FISH & Prognosis [depends on abnormality] & {$[121-122]$} \\
\hline
\end{tabular}


Table 2 (continued)

\begin{tabular}{|c|c|c|c|c|}
\hline $\begin{array}{l}\text { Haematological } \\
\text { malignancy }\end{array}$ & Genomic variant & $\begin{array}{l}\text { Current } \\
\text { technique(s) for } \\
\text { detection* }\end{array}$ & Clinical utility & Reference(s) \\
\hline $\begin{array}{l}\text { Chronic } \\
\text { lymphocytic } \\
\text { leukaemia }\end{array}$ & IgHV mutated or unmutated status & NGS; (SS) & $\begin{array}{l}\text { Prognosis [unmutated = poor]; Helps } \\
\text { inform choice of treatment }\end{array}$ & {$[123-126]$} \\
\hline $\begin{array}{l}\text { Chronic } \\
\text { lymphocytic } \\
\text { leukaemia }\end{array}$ & TP53 disruption & FISH; NGS & $\begin{array}{l}\text { Prognosis [poor]; Informs treatment } \\
\text { choice }\end{array}$ & {$[127-129]$} \\
\hline $\begin{array}{l}\text { Chronic } \\
\text { lymphocytic } \\
\text { leukaemia }\end{array}$ & BTK, PLCG2 mutations & NGS; (SS) & $\begin{array}{l}\text { Targeted treatment (confers resistance to } \\
\text { BTK inhibitors) }\end{array}$ & {$[130]$} \\
\hline $\begin{array}{l}\text { Plasma cell } \\
\text { myeloma }\end{array}$ & $\begin{array}{l}\operatorname{del}(17 \mathrm{p}), \mathrm{t}(4 ; 14), \mathrm{t}(14 ; 16), \mathrm{t}(14 ; 20), \\
\quad \text { non-hyperdiploidy, del }(1 \mathrm{p}) \text {, gain }(1 \mathrm{q})\end{array}$ & FISH & $\begin{array}{l}\text { Prognosis [poor]; Helps inform choice } \\
\text { of treatment }\end{array}$ & {$[132-134]$} \\
\hline $\begin{array}{l}\text { Plasma cell } \\
\text { myeloma }\end{array}$ & Immunoglobulin gene rearrangement & QF-PCR & Disease response; MRD & {$[137]$} \\
\hline
\end{tabular}

*The techniques indicated represent the commonest ways of delivering testing in routine practice. However, other techniques are available, e.g. microarray in place of karyotyping, amplification refractory mutation system [ARMS] PCR for mutation detection. Although SS can detect many similar small variants to NGS, its sensitivity is far lower (hence its placement in brackets in many instances). TKI tyrosine kinase inhibitor; MRD minimal/measurable residual disease

$F I S H$ fluorescence in situ hybridisation, $R T-P C R$ reverse-transcriptase polymerase chain reaction, $N G S$ next generation sequencing, $Q F-P C R$ quantitative fluorescence polymerase chain reaction, $S S$ Sanger sequencing

critical gene target of many of these structural abnormalities remains unknown [135].

Although some recurrently mutated genes have been described in myeloma (e.g. $B R A F, N R A S, K R A S$ ), unlike in other malignancies, these are not typically targeted therapeutically. Reasons for this include mutations being outside typical hotspots (i.e. $\sim 50 \% B R A F$ mutations are not at codon 600 ), being sub-clonal or the presence of two or more clonal mutations in the same pathway (i.e. MAPK pathway) meaning responses to a single inhibitor are likely to be limited [135]. The subclonality of myeloma is notable for both small variants and structural abnormalities and shows evidence of both divergent and linear evolution. Its presence raises questions about the utility of targeted approaches in this disease [136].

Similar to other B cell-derived malignancies the presence of unique $\mathrm{VDJ} / \mathrm{VJ}$ rearrangements in the BCR provides a target for MRD. Studies have shown that MRD negativity determined using NGS with a sensitivity of $1-i n-10^{6}$ is associated with better progression free survival raising the possibility that this can be used to adapt treatment intensity as seen in ALL trials [137].

\section{Changing Technologies}

Tables 1 and 2 (myeloid and lymphoid disorders respectively) summarise the testing described above together with its clinical utility and the common technologies used in its delivery. These tables demonstrate that many disease subtypes, e.g. acute myeloid leukaemia undergo multi-modality testing with each assay looking for a different genomic abnormality. With increasing breadth of the genome being clinically actionable, there is a move towards more comprehensive testing such as that delivered by WGS. Within England, building on the 100,000 Genomes Project, WGS will be made available through the National Health Service for all acute leukaemias (as specified in the National Genomic Test Directory for Cancer) [138, 139].

Upon robust demonstration of equivalence to existing techniques, and with availability of clinically relevant turn-around times, it is envisaged WGS will be able to replace a number of individual assays with a single test; particularly advantageous if there is limited sample or no viable cells (necessary for karyotyping). It should be noted, however, that the present turn-around times and sensitivity of WGS mean it is unsuitable for replacing very rapid (e.g. FISH for $\mathrm{t}(15 ; 17)$ in suspected APML) or high sensitivity testing (e.g. MRD). Nevertheless the technique has the advantage of covering the full breadth of the genome including germline data and subject to appropriate patient consent, WGS coupled with high quality clinical data will provide a research resource that can be interrogated for novel genomic information (including the non-coding regions) to inform prognosis and suggest possible new targets for therapeutic approaches.

\section{Conclusion}

Building on early cytogenetic and FISH data and now utilising NGS technologies, genomic information remains central to the diagnosis, risk stratification and treatment choice in 
haematological malignancies. Increasingly multiple aberrations are being combined to produce new classifications of disease and more accurate prognostic information. The challenge now is how this information can be derived in a timely fashion after diagnosis and used to deploy novel targeted therapies in development, including in clinical trials, to improve outcomes. Equally the relevance of the persistence of any particular abnormality post-treatment and as to whether this represents true MRD remains to be fully determined.

\section{Compliance with Ethical Standards}

Conflict of Interest Dr. Hamblin reports personal fees as a member of the Advisory Board for Novartis; personal fees as a member of the Speakers Bureau for Pfizer, Roche, Gilead, and Jazz; and remuneration for data analysis from CTI.

Dr. Bruce, Dr. Timbs, and Dr. Veenstra each declare no conflict of interest.

Human and Animal Rights and Informed Consent This article does not contain any studies with human or animal subjects performed by any of the authors.

Open Access This article is distributed under the terms of the Creative Commons Attribution 4.0 International License (http:// creativecommons.org/licenses/by/4.0/), which permits unrestricted use, distribution, and reproduction in any medium, provided you give appropriate credit to the original author(s) and the source, provide a link to the Creative Commons license, and indicate if changes were made.

\section{References}

Papers of particular interest, published recently, have been highlighted as:

- Of importance

- Of major importance

1. Nowell PC, Hungerford DA. A minute chromosome in human chronic granulocytic leukemia. Science. 1960;142:1497.

2. Rowley JD. A new consistent chromosomal abnormality in chronic myelogenous leukemia identified by quinacrine fluorescence and Giemsa staining. Nature. 1973;242:290-3. https://doi.org/10. 1038/243290a0.

3. Shtivelman E, Lifshitz B, Gale R, Canaani E. Fused transcript of $\mathrm{abl}$ and bcr genes in chronic myelogenous leukaemia. Nature. 1985;315:550-4. https://doi.org/10.1038/315550a0.

4. Lugo TG, Pendergast AM, Muller AJ, Witte ON. Tyrosine kinase and transformation potency of bcr-abl oncogene products. Science. 1990;247:1079-82. https://doi.org/10.1126/science. 2408149

5. Daley GQ, Van Etten RA, Baltimore D. Induction of chronic myelogenous leukemia in mice by the P210bcr/abl gene of the Philadelphia chromosome. Science. 1990;247:824-30. https:// doi.org/10.1126/science.2406902.

6. Arber DA, Orazi A, Hasserjian R, Thiele J, Borowitz MJ, Le Beau MM, et al. The 2016 revision to the World Health Organization classification of myeloid neoplasms and acute leukemia. Blood.
2016;127:2239-405. https://doi.org/10.1182/blood-2016-03643544. Summary of changes to WHO Classification of myeloid malignancies including updates about the role of genomic information.

7. Baccarani M, Deininger MW, Rosti G, Hocchaus A, Soverini S, Apperley JF, et al. European LeukemiaNet recommendations for the management of chronic myeloid leukemia: 2013. Blood. 2013;122:872-84. https://doi.org/10.1182/blood-2013-05501569.

8. Druker BJ, Tamura S, Buchdunger E, Ohno S, Segal GM, Fanning $\mathrm{S}$, et al. Effects of a selective inhibitor of the Abl tyrosine kinase on the growth of Bcr-Abl positive cells. Nat Med. 1996;2:561-6. https://doi.org/10.1038/nm0596-561.

9. Rosti G, Castagnetti F, Gugliotta G, Baccarani M. Tyrosine kinase inhibitors in chronic myeloid leukaemia: which, when, for whom? Nat Rev Clin Oncol. 2017;14:141-54. https://doi.org/10.1038/ nrclinonc.2016.139.

10. O’Brien SG, Guilhot F, Larson RA, Gathmann I, Baccarani M, Cervantes $\mathrm{F}$, et al. Imatinib compared with interferon and lowdose cytarabine for newly diagnosed chronic-phase chronic myeloid leukemia. N Engl J Med. 2003;348:994-1004. https://doi.org/ 10.1056/NEJMoa022457.

11. Cross NCP, White HE, Colomer D, Ehrencrona H, Foroni L, Gottardi E, et al. Laboratory recommentations for scoring deep molecular responses following treatment for chronic myeloid leukemia. Leukemia. 2015;29:999-1003. https://doi.org/10.1038/ leu.2015.29. Summary of the recommended implementation of MRD measurement in CML.

12. Etienne G, Guilhot J, Rea D, Rigal-Huguet F, Nicolini F, Charbonnier A, et al. Long-term follow-up of the French stop imatinib (STIM1) study in patients with chronic myeloid leukemia. J Clin Oncol. 2017;35:298-305. https://doi.org/10.1200/ JCO.2016.68.2914.

13. Shah NP, Nicoll JM, Nagar B, Gorre ME, Paquette RL, Kurivan J, et al. Multiple BCR-ABL kinase domain mutations confer polyclonal resistance to the tyrosine kinase inhibitor imatinib (STI571) in chronic phase and blast crisis chronic myeloid leukemia. Cancer Cell. 2002;2:117-25. https://doi.org/10.1016/S1535-6108(02) 00096-X.

14. Cortes JE, Kim DW, Pinilla-Ibarz J, le Coutre P, Paquette R, Chuah C, et al. A phase 2 trial of ponatinib in Philadelphia chromosome-positive leukemias. N Engl J Med. 2013;369: 1783-96. https://doi.org/10.1056/NEJMoa1306494.

15. Kizilors A, Crisà E, Lea N, Passera R, Mian S, Anwar J, et al. Effect of low-level BCR-ABL1 kinase domain mutations identified by next-generation sequencing in patients with chronic myeloid leukaemia: a population-based study. Lancet Haematol. 2019;6:e276-84. https://doi.org/10.1016/S2352-3026(19)300274.

16. Cazzola M. Introduction to a review series: the 2016 revision of the WHO classification of hematopoietic and lymphoid tissues. Blood. 2016;127:2361-4. https://doi.org/10.1182/blood-201603-657379.

17.• WHO classification of tumours of haematopoietic and lymphoid tissues. In: Werdlow SH, Campo E, Harris NL, Jaffe ES, Pileri SA, Stein $\mathrm{H}$ et al., editors. WHO Classification of Tumours, Revised $4^{\text {th }}$ Edition, Volume 2. IARC: 2017 . Updated WHO classification of haematological malignancies incorporating extensive genomic data.

18.• Papaemmanuil E, Gerstung M, Bullinger L, Gaidzik VI, Paschka P, Roberts ND, et al. Genomic classification and prognosis in acute myeloid leukemia. N Engl J Med. 2016;374:2209-21. https://oi.org/10.1056/NEJMoa1516192. Example of the use of combinations of genomic abnormalities to classify AML which correlates with observed prognosis. 
19. Cancer Genome Atlas Reseach Network, Ley TJ, Miller C, Ding L, Raphael BJ, Mungall AJ, et al. Genomic and epigenomic landscapes of adult de novo acute myeloid leukemia. N Engl J Med. 2013;368:2059-74. https://doi.org/10.1056/NEJMoa1301689.

20. Grimwade D, Hills RK, Moorman AV, Walker H, Chatters S, Goldstone AH, et al. Refinement of cytogenetic classification in acute myeloid leukemia: determination of prognostic significance of rare recurring chromosomal abnormalities among 5876 younger adult patients treated in the United Kingdom Medical Research Council trials. Blood. 2010;116:354-65. https://doi. org/10.1182/blood-2009-11-254441.

21. Dohner H, Estey E, Grimwade D, Amadori S, Appelbaum FR, Buchner T, et al. Diagnosis and management of AML in adults: 2017 ELN recommendations from an international expert panel. Blood. 2017;129:424-47. https://doi.org/10.1182/blood-2016-08733196. International recommendations on the management of $A M L$ including required genomic testing.

22. O'Donnell MR, Tallman MS, Abboud CN, Altman JK, Appelbaum FR, Arber DA, et al. Acute Myeloid Leukemia, Version 3.2017, NCCN clinical practice guidelines in oncology. J Natl Compr Cancer Netw. 2017;(15):926-57. https://doi.org/10. 6004/jncen.2017.0116.

23. Lo-Coco F, Avvisati G, Vignetti M, Thiede C, Orlando SM, Iacobelli $\mathrm{S}$, et al. Retinoic acid and arsenic trioxide for acute promyelocytic leukemia. N Eng1 J Med. 2013;369:111-21. https://doi.org/10.1056/NEJMoa1300874.

24. Hills RK, Castaigne S, Appelbaum FR, Delaunay J, Petersdorf S, Othus M, et al. Addition of gemtuzumab ozogamicin to induction chemotherapy in adult patients with acute myeloid leukaemia: a meta-anaysis of individual patient data from randomised controlled trials. Lancet Oncol. 2014;15:986-96. https://doi.org/10. 1016/S1470-2045(14)70281-5.

25. Gottardi M, Mosna F, de Angeli S, Papayannidis C, Candoni A, Clavio M, et al. Clinical and experimental efficacy of gemtuzumab ozogamicin in core binding factor acute myeloid leukemia. Haematol Rep. 2017;9:7029. https://doi.org/10.4081/hr.2017. 7028.

26. Majhail NS, Farnia SH, Carpenter PA, Champlin RE, Crawford S, Marks DI, et al. Indications for autologous and allogeneic hematopoietic cell transplantation: guidelines from the American Society for Blood and Marrow Transplantation. Biol Blood Marrow Transplant. 2015;21:1863-9. https://doi.org/10.1016/j. bbmt.2015.07.032.

27. Grimwade D, Jovanovic JV, Hills RK, Nugent EA, Patel Y, Flora R. Prospective minimal residual disease monitoring to predict relapse of acute promyelocytic leukemia and to direct pre-emptive arsenic trioxide therapy. J Clin Oncol. 2009;27:2650-8. https:// doi.org/10.1200/JCO.2008.20.1533.

28. Yin JA, O'Brien MA, Hills RK, Daly SB, Wheatley K, Burnett AK. Minimal residual disease monitoring by quantitative RT-PCR in core binding factory AML allows risk stratification and predicts relapse: results of the United Kingdom MRC AML-15 trial. Blood. 2012;120:2826-35. https://doi.org/10.1182/blood-201206-435669.

29. Falini B, Mecucci C, Tiacci E, Alcalay M, Rosati R, Pasqualucci $\mathrm{L}$, et al. Cytoplasmic nucloephosmin in acute myelogenous leukemia with a normal karyotype. N Engl J Med. 2005;352:254-66. https://doi.org/10.1056/NEJMoa041974.

30. Dufour A, Schneider F, Metzeler KH, Hoster E, Schneider S, Zellmeier E, et al. Acute myeloid leukaemia with biallelic CEBPA gene mutations and normal karyotype represents a distinct genetic entity associated with a favourable clinical outcome. J Clin Oncol. 2010;28:570-7. https://doi.org/10.1200/JCO.2008. 21.6010 .

31. Schlenk RF, Dohner K, Krauter J, Frohling S, Corbacioglu A, Bullinger L, et al. Mutations and treatment outcome in cytogenetically normal acute myeloid leukemia. N Engl J Med. 2008;358:1909-18. https://doi.org/10.1056/NEJMoa074306.

32.• Ivey A, Hills RK, Simpson MA, Jovanovic JV, Gilkes A, Grech A, et al. Assessment of minimal residual disease in standard risk AML. N Engl J Med. 2016;374:422-33. https://doi.org/10.1056/ NEJMoa1507471. Evidence of the utility of NPM1 MRD measurement in AML to predict relapse risk.

33. Schnittger S, Schoch C, Dugas M, Kern W, Staib P, Wuchter C, et al. Analysis of FLT3 length mutations in 1003 patients with acute myeloid leukemia: correlation to cytogenetics, FAB subtype, and prognosis in the AMLCG study and usefulness as a marker for the detection of minimal residual disease. Blood. 2002;100:59-66. https://doi.org/10.1182/blood.V100.1.59.

34. Gale R, Green C, Allen C, Mead AJ, Burnett AK, Hills RK, et al. The impact of FLT3 internal tandem duplication mutant level, number, size, and interaction with NPM1 mutations in a large cohort of young adult patients with acute myeloid leukemia. Blood. 2008;111:2776-84. https://doi.org/10.1182/blood-200708-109090.

35. Schnittger S, Eder C, Jeromin S, Alpermann T, Fasan A, Grossmann V, et al. ASXL1 exon 12 mutations are frequent in AML with intermediate risk karyotype an are independently associated with an adverse outcome. Leukemia. 2013;27:82-91. https://doi.org/10.1038/leu.2012.262.

36. Gaidzik VI, Teleanu V, Papaemmanuil E, Weber D, Paschka P, Hahn J, et al. RUNX1 mutations in acute myeloid leukemia are associated with distinct clinic-pathologic and genetic features. Leukemia. 2016;30:2160-8. https://doi.org/10.1038/leu.2016. 126.

37. Bowen D, Groves MJ, Burnett AK, Patel Y, Allen C, Green C, et al. TP53 gene mutation is frequent in patients with acute myeloid leukemia and complex karyotype, and is associated with very poor prognosis. Leukemia. 2009;23:203-6. https://doi.org/10. 1038/leu.2008.173.

38. Stone RM, Mandrekar SJ, Sanford BL, Laumann K, Geyer S, Bloomfield CD, et al. Midostaurin plus chemotherapy for acute myeloid leukemia with a FLT3 mutation. N Engl J Med. 2017;377:454-64. https://doi.org/10.1056/NEJMoa1614359. Description of the utility of specifically targeting FLT3 mutations in AML.

39. Mead AJ, Linch DC, Hills RK, Wheatley K, Burnett AK, Gale RE. FLT3 tyrosine kinase domain mutations are biologically distinct from and have a significantly more favourable prognosis than FLT3 internal tandem duplications in patients with acute myeloid leukemia. Blood. 2007;110:1262-70. https://doi.org/10.1182/ blood-2006-04-015826.

40. Lindsley RC, Mar BG, Mazzola E, Grauman PV, Shareef S, Allen $\mathrm{SL}$, et al. Acute myeloid leukemia ontogeny is defined by distinct somatic mutations. Blood. 2015;125:1367-76. https://doi.org/10. 1182/blood-2014-11-610543.

41. Stein EM, DiNardo CD, Pollyea DA, Fathi AT, Roboz GJ, Altman $\mathrm{JK}$, et al. Enasidenib in mutant $I D H 2$ relapsed or refractory acute myeloid leukemia. Blood. 2017;130:722-31. https://doi.org/10. 1182/blood-2017-04-779405.

42. DiNardo CD, Stein EM, de Botton S, Roboz GJ, Altman JK, Mims AS, et al. Durable remissions with ivosidenib in IDH1mutated relapsed or refractory AML. N Engl J Med. 2018;378: 2286-398. https://doi.org/10.1056/NEJMoa1716984.

43. Jongen-Lavrencic M, Grob T, Hanekamp D, Kavelaars FG, Al Hinai A, Zeilemaker A, et al. Molecular minimal residual disease in acute myeloid leukemia. N Engl J Med. 2018;378:1189-99. https://doi.org/10.1056/NEJMoa1716863. Description of the variation in significance of the persistence of different mutations during MRD measurement in AML in relation to relapse risk. 
44. Greenberg P, Cox C, LeBeau MM, Fenaux P, Morel P, Sanz G, et al. International scoring system for evaluating prognosis in myelodysplastic syndromes. Blood. 1997;89:2079-88.

45. Schanz J, Tuchler H, Sole F, Mallo M, Luno E, Cervera J, et al. New comprehensive cytogenetic scoring system for primary myelodysplastic syndromes (MDS) and oligoblastic acute myeloid leukemia after MDS derived from an international database merge. J Clin Oncol. 2012;30:820-9. https://doi.org/10.1200/ JCO.2011.35.6394

46. Greenberg PL, Tuechler H, Schanz J, Sanz G, Garcia-Manero G, Sole F, et al. Revised international prognostic scoring system for myelodysplastic syndromes. Blood. 2012;120:2454-65. https:// doi.org/10.1182/blood-2012-03-420489.

47. Kokate P, Dalvi R, Koppaka N, Mandava S. Prognostic classification of MDS is improved by the inclusion of FISH panel testing with conventional cytogenetics. Cancer Gene Ther. 2017;216217:120-7. https://doi.org/10.1016/j.cancergen.2017.05.004.

48. Da Silva FB, Machado-Neto JA, Bertini VHLL, Velloso EDRP, Ratis CA, Calado RT, et al. Single-nucleotide polymorphism array (SNP-A) improves the identification of chromosomal abnormalities by metaphase cytogenetics in myelodysplastic syndrome. $\mathrm{J}$ Clin Pathol. 2017;70:435-42. https://doi.org/10.1136/jclinpath2016-204023.

49. Haase D, Germing U, Schanz J, Pfeilstocker M, Nosslinter T, Hildebrandt B, et al. New insights into the prognostic impact of the karyotype in MDS and correlation with subtypes: evidence from a core dataset of 2124 patients. Blood. 2007;110:4385-95. https://doi.org/10.1182/blood-2007-03-082404.

50. Fenaux P, Giagounidis A, Selleslag D, Beyne-Rauzy O, Mufti G, Mittleman M, et al. A randomised phase 3 study of lenalidomide versus placebo in RBC transfusion-dependent patients with low-/ intermediate-1-risk myelodysplastic syndromes with del5q. Blood. 2011;118:3765-76. https://doi.org/10.1182/blood-201101-330126.

51. Jadersten M, Saft L, Smith A, Kulasekararaj A, Pomplun S, Gohring G, et al. TP53 mutations in low-risk myelodysplastic syndromes with del $(5 q)$ predict disease progression. J Clin Oncol. 2011;20:1971-9. https://doi.org/10.1200/JCO.2010.31. 8576.

52. Lode L, Menard A, Flet L, Richebourg S, Loirat M, Eveillard M, et al. Emergence and evolution of TP53 mutations are key features of disease progression in myelodysplastic patients with lower-risk $\operatorname{del}(5 q)$ treated with lenalidomide. Haematologica. 2018;103: e143-6. https://doi.org/10.3324/haeamtol.2017.181404.

53. Bejar R, Stevenson K, Abdel-Wahab O, Galili N, Nilsson B, Garcia-Manero G, et al. Clinical effect of point mutations in myelodysplastic syndromes. N Engl J Med. 2011;364:2496-506. https://doi.org/10.1056/NEJMoa1013343.

54. Hafaerlach T, Nagata Y, Grossmann V, Okuno Y, Bacher U, Nagae $\mathrm{G}$, et al. Landscape of genetic lesions in 944 patients with myelodysplastic syndromes. Leukemia. 2014;28:241-7. https:// doi.org/10.1038/leu.2013.336. Description of genomic heterogeneity of MDS.

55. Papaemmanuil E, Gerstung M, Malcovati L, Tauro S, Gundem G, Van Loo P, et al. Clinical and biological implications of driver mutations in myelodysplastic syndromes. Blood. 2013;122: 3616-27. https://doi.org/10.1182/blood-2013-08-518886.

56. Malcovati L, Karimi M, Papaemmanuil E, Ambaglio L, Jadersten M, Jansson M, et al. SF3B1 mutations identifies a distinct subset of myelodysplastic syndrome with ring sideroblasts. Blood. 2015;126:233-41. https://doi.org/10.1182/blood-2015-03633537.

57. Platzbecker U, Germing U, Gotze KS, Kiewe P, Mayer K, Chromik J, et al. Luspatercept for the treatment of anaemia in patients with lower-risk myelodysplastic syndromes (PACEMDS): a multicentre, open-label phase 2 dose-finding study with long-term extension study. Lancet Oncol. 2017;18:1338-47. https://doi.org/10.1016/S1470-2045(17)30615-0.

58. Gangat N, Mudireddy M, Lasho TL, Finke CM, Nicolosi M, Szuber N, et al. Mutations and prognosis in myelodysplastic syndromes: karyotype-adjusted analysis of targets sequencing in 200 consecutive cases and development of a genetic risk model. Am J Hematol. 2018;93:691-7. https://doi.org/10.1002/ajh.25064.

59. Lindsley RC, Saber W, Mar BG, Redd R, Wang T, Haagenson $\mathrm{MD}$, et al. Prognostic mutations in myelodysplastic syndrome after stem-cell transplantation. N Engl J Med. 2017;376:536-47. https://doi.org/10.1056/NEJMoa1611604. Evidence that mutational status in MDS pre-transplant influences longterm outcome.

60. Tobiasson M, Kittang AO. Treatment of myelodysplastic syndrome in the era of next-generation sequencing. J Intern Med. 2019;286:41-62. https://doi.org/10.1111/joim.12893.

61. Jaiswal S, Fontanillas P, Flannick J, Manning A, Grauman PV, Mar BG, et al. Age-related clonal hematopoiesis associated with adverse outcomes. N Engl J Med. 2014;371:2488-98. https://doi. org/10.1056/NEJMoa1408617. Description of CHIP and potential clinical implications.

62. Genovese G, Kähler AK, Handsaker RE, Lindberg J, Rose SA, Bakhoum SF, et al. Clonal hematopoiesis and blood-cancer risk inferred from blood DNA sequence. N Engl J Med. 2014;371: 2477-87. https://doi.org/10.1056/NEJMoa1409405.

63. Gibson CJ, Lindsley RC, Tchekmedyian V, Mar BG, Shi J, Jaiswal S, et al. Clonal hematopoiesis associated with adverse outcomes after autologous stem-cell transplantation for lymphoma. J Clin Oncol. 2017;35:1598-605. https://doi.org/10.1200/ JCO.2016.71.6712. Relevance of CHIP mutations in the context of autologous HSCT.

64. Kralovics R, Passamonti F, Buser AS, Teo SS, Tiedt R, Passweg JR, et al. A gain-of-function mutation of JAK2 in myeloproliferative disorders. N Engl J Med. 2005;352:1779-90. https://doi.org/ 10.1056/NEJMoa051113.

65. Vainchenker W, Kralovics R. Genetic basis and molecular pathophysiology of classical myeloproliferative neoplasms. Blood. 2017;129:667-79. https://doi.org/10.1182/blood-2016-10695940.

66. Scott LM, Tong W, Levine RL, Scott MA, Beer PA, Stratton MR, et al. JAK2 exon 12 mutations in polycythemia vera and idiopathic erythrocytosis. N Engl J Med. 2007;356:459-68. https://doi.org/ 10.1056/NEJMoa065202.

67. Pardanani AD, Levine RL, Lasho T, Pikman Y, Mesa RA, Wadleigh M, et al. MPL515 mutations in myeloproliferative and other myeloid disorders: a study of 1182 patients. Blood. 2006;108:3472-6. https://doi.org/10.1182/blood-2006-04018879 .

68. Nangalia J, Massie CE, Baxter EJ, Nice FL, Gundem G, Wedge DC, et al. Somatic CALR mutations in myeloproliferative neoplasms with nonmutated JAK2. N Engl J Med. 2013;369:2391405. https://doi.org/10.1056/NEJMoa1312542.

69. Klampfl T, Gisslinger H, Harutyunyan AS, Nivarthi H, Rumi E, Milosevic JD, et al. Somatic mutations of calreticulin in myeloproliferative neoplasms. N Engl J Med. 2013;369:2379-90. https://doi.org/10.1056/NEJMoa1311347.

70. Harrison C, Kiladjian JJ, Al-Ali HK, Gisslinger H, Waltzman R, Stalbovskaya V, et al. JAK inhibition with ruxolitinib versus best available therapy for myelofibrosis. N Engl J Med. 2012;366:78798. https://doi.org/10.1056/NEJMoa1110556.

71. Vannucchi AM, Lasho TL, Guglielmelli P, Biamonte F, Pardanani A, Pereira A, et al. Mutations and prognosis in primary myelofibrosis. Leukemia. 2013;27:1861-9. https://doi.org/10.1038/leu. 2013.119.

72. Tefferi A, Guglielmelli P, Lasho TL, Gangat N, Ketterling RP, Pardanani A, et al. MIPSS70+ Version 2.0: mutation and 
karyotype-enhanced international prognostic scoring system for primary myelofibrosis. J Clin Oncol. 2018;36:1769-70. https:// doi.org/10.1200/JCO.2018.78.9867. Incorporation of genomic information with clinical phenotype to develop a prognostic scoring system in PMF.

73.• Grinfeld J, Nangalia J, Baxter EJ, Wedge DC, Angelopoulos N, Cantrill R, et al. Classification and personalized prognosis in myeloproliferative neoplasms. N Engl J Med. 2018;379:1416-30. https://doi.org/10.1056/NEJMoa1716614. The use of the combination of genetic and clinical factors to predict risk of transformation and death in MPNs.

74. Nagata H, Worobec AS, Oh CK, Chowdhury BA, Tannenbaum S, Suzuki Y, et al. Identification of a point mutation in the catalytic domain of the protooncogene c-kit in peripheral blood mononuclear cells of patients who have mastocytosis with an associated hematologic disorder. Proc Natl Acad Sci U S A. 1995;92:10560 4. https://doi.org/10.1073/pnas.92.23.10560.

75. Fletcher L, Borate U. Novel approaches for systemic mastocytosis. Curr Opin Hematol. 2019;26:112-8. https://doi. org/10.1097/MOH.0000000000000486.

76. Maxson JE, Gotlib J, Pollyea DA, Fleischman AG, Agarwal A, Eide CA, et al. Oncogenic CSF3R mutations in chronic neutrophilic leukemia and atypical CML. N Engl J Med. 2013;368: 1781-90. https://doi.org/10.1056/NEJMoa1214514.

77. Reiter A, Gotlib J. Myeloid neoplasms with eosinophilia. Blood. 2017;129:704-14. https://doi.org/10.1182/blood-2016-10695973.

78. Patel BJ, Przychodzen B, Thota S, Radivoyevitch T, Visconte V, Kuzmanovic, et al. Genomic determinants of chronic myelomonocytic leukemia. Leukemia. 2017;31:2815-23. https:// doi.org/10.1038/leu.2017.164.

79. Malcovati L, Papaemmanuil E, Bowen DT, Boultwood J, Della Porta MG, Pascutto C, et al. Clinical significance of SF3B1 mutations in myelodysplastic syndromes and myelodysplastic/ myeloproliferative neoplasms. Blood. 2011;118:6239-46. https:// doi.org/10.1182/blood-2011-09-377275.

80. Roberts KG, Mullighan CG. Genomics in acute lymphoblastic leukaemia: insights and treatment implications. Nat Rev Clin Oncol. 2015;12:344-57. https://doi.org/10.1038/nrclinonc.2015. 38.

81. Pui CH, Nichols KE, Yang JJ. Somatic and germline genomics in paediatric acute lymphoblastic leukaemia. Nat Rev Clin Oncol. 2019;16:227-40. https://doi.org/10.1038/s41571-018-0136-6.

82. Secker-Walker LM, Lawler SD, Hardisty RM. Prognostic implications of chromosomal findings in acute lymphoblastic leukaemia at diagnosis. Br Med J. 1978;2:1529-30. https://doi.org/10. 1136/bmj.2.6151.1529.

83. Moorman AV, Harrison CJ, Buck GAN, Richards SM, SeckerWalker LM, Martineau M, et al. Karyotype is an independent prognostic factor in adult acute lymphoblastic leukemia (ALL): analysis of cytogenetic data from patients treated on the Medical Research Council (MRC) UKALLXII/Eastern Cooperative Oncology Group (ECOG) 2993 trial. Blood. 2007;109:3189-97. https://doi.org/10.1182/blood-2006-10-051912.

84. Romana SP, Le Coniat M, Berger R. T(12;21): a new recurrent translocation in acute lymphoblastic leukemia. Genes Chromosom Cancer. 1994;9:186-91. https://doi.org/10.1002/gcc.2870090307.

85. Moorman AV, Robinson H, Schwab C, Richards SM, Hancock J, Mitchell CD, et al. Risk-directed treatment intensification significantly reduces the risk of relapse among children and adolescents with acute lymphoblastic leukemia and intrachromosomal amplification of chromosome 21: a comparison of the MRC ALL97/99 and UKALL2003 trials. J Clin Oncol. 2013;31:3389-96. https:// doi.org/10.1200/JCO.2013.48.9377.

86. Schultz KR, Carroll A, Heerema NA, Bowman WP, Aledo A, Slayton WB, et al. Long-term follow-up of imatinib in pediatric
Philadelphia chromosome-positive acute lymphoblastic leukemia: Children's oncology group study AALL0031. Leukemia. 2014;28:1467-71. https://doi.org/10.1038/leu.2014.30.

87. Den Boer ML, van Slegtenhorst M, De Menezes RX, Cheok MH, Buijs-Gladdines JG, Peters ST, et al. A subtype of childhood acute lymphoblastic leukaemia with poor treatment outcome: a genomewide classification study. Lancet Oncol. 2009;10:125-34. https:// doi.org/10.1016/S1470-2045(08)70339-5.

88. Roberts KG, Li Y, Payne-Turner D, Harvey RC, Yang YL, Pei D, et al. Targetable kinase-activating lesions in Ph-like acute lymphoblastic leukemia. N Engl J Med. 2014;371:1005-15. https://doi. org/10.1056/NEJMoa1403088. The use of different TKIs in Phlike ALL underpinned by different activating genomic abnormalities.

89. Belver L, Ferrando A. The genetics and mechanisms of T cell acute lymphoblastic leukaemia. Nat Rev Cancer. 2016;16:494 507. https://doi.org/10.1038/nrc.2016.63.

90. Korsmeyer SJ, Arnold A, Bakhshi A, Ravetch JV, Siebenlist U, Hieter PA, et al. Immunoglobulin gene rearrangement and cell surface antigen expression in acute lymphocytic leukemias of $\mathrm{T}$ cell and B cell precursor origins. J Clin Invest. 1983;71:301-13. https://doi.org/10.1172/jci110770.

91. Waldmann TA, Davis MM, Bongiovanni KF, Korsmeyer SJ. Rearrangements of genes for the antigen receptor on $\mathrm{T}$ cells as markers of lineage and clonality in human lymphoid neoplasms. N Engl J Med. 1985;313:776-83. https://doi.org/10.1056/ NEJM198509263131303.

92.• Berry DA, Zhou S, Higley H, Mukundan L, Fu S, Reaman GH, et al. Association of minimal residual disease with clinical outcome in pediatric and adult acute lymphoblastic leukemia: a metaanalysis. JAMA Oncol. 2017;3:e170580. https://doi.org/10.1001/ jamaoncol.2017.0580. The role of MRD in predicting outcome in ALL.

93. Pieters R, de Groot-Kruseman H, Van der Velden V, Fiocco M, van den Berg H, de Bont E, et al. Successful therapy reduction and intensification for childhood acute lymphoblastic leukemia based on minimal residual disease monitoring: study ALL10 from the Dutch Childhood Oncology Group. J Clin Oncol. 2016;34:2591601. https://doi.org/10.1200/JCO.2015.64.6364. The use of MRD in ALL to intensify and de-intensify treatment.

94. Rosenthal A, Younes A. High grade B-cell lymphoma with rearrangements of MYC and BCL2 and/or BCL6: double hit and triple hit lymphomas and double expressing lymphoma. Blood Rev. 2017;31:37-42. https://doi.org/10.1016/j.blre.2016.09.004.

95. Rosenwald A, Bens S, Advani R, Barrans S, Copie-Bergman C, Elsensohn MH, et al. Prognostic significance of MYC rearrangement and translocation partner in diffuse large b-cell lymphoma: a study by the Lunenburg Lymphoma Biomarker Consortium. J Clin Oncol. 2019. https://doi.org/10.1200/JCO.19.00743. The significance of $M Y C$ translocation partner in double and triple hit DLBCL.

96. Alizadeh AA, Eisen MB, Davis RE, Ma C, Lossos IS, Rosenwald A, et al. Distinct types of diffuse large B-cell lymphoma identified by gene expression profiling. Nature. 2000;403:503-11. https:// doi.org/10.1038/35000501.

97. Jais JP, Haioun C, Molina TJ, Rickman DS, de Reynies A, Berger F, et al. The expression of 16 genes related to the cell of origin and immune response predicts survival in elderly patients with diffuse large B-cell lymphoma treated with CHOP and rituximab. Leukemia. 2008;22:1917-24. https://doi.org/10.1038/leu.2008.188.

98. Lohr JG, Stojanov P, Lawrence MS, Auclair D, Chapuy B, Sougnez C, et al. Discovery and prioritization of somatic mutations in diffuse large B-cell lymphoma (DLBCL) by whole-exome sequencing. Proc Natl Acad Sci U S A. 2012;109:3879-84. https://doi.org/10.1073/pnas.1121343109. 
99. Morin RD, Mendez-Lago M, Mungall AJ, Goya R, Mungall KL, Corbett RD, et al. Frequent mutation of histone-modifying genes in non-Hodgkin lymphoma. Nature. 2011;476:298-303. https:// doi.org/10.1038/nature10351.

100. Chapuy B, Roemer MG, Stewart C, Tan Y, Abo RP, Zhang L, et al. Targetable genetic features of primary testicular and primary central nervous system lymphomas. Blood. 2016;127:869-81. https:// doi.org/10.1182/blood-2015-10-673236.

101. Gunawardana J, Chan FC, Telenius A, Woolcock B, Kridel R, Tan $\mathrm{KL}$, et al. Recurrent somatic mutations of PTPN1 in primary mediastinal B cell lymphoma and Hodgkin lymphoma. Nat Genet. 2014;46:329-35. https://doi.org/10.1038/ng.2900.

102. Schmitz R, Wright GW, Huang DW, Johnson CA, Phelan JD, Wang JQ, et al. Genetics and pathogenesis of diffuse large B-cell lymphoma. N Engl J Med. 2018;378:1396-407. https://doi.org/ 10.1056/NEJMoa1801445.

103.• Chapuy B, Stewart C, Dunford AJ, Kim J, Kamburov A, Redd RA, et al. Molecular subtypes of diffuse large B cell lymphoma are associated with distinct pathogenic mechanisms and outcomes. Nat Med. 2018;24:679-90. https://doi.org/10.1038/s41591-0180016-8. The use of combinations of genomic abnormalities to classify DLBCL and its correlation with clinical outcome.

104. Roschewski M, Dunleavy K, Pittaluga S, Moorhead M, Pepin F, Kong K, et al. Circulating tumour DNA and CT monitoring in patients with untreated diffuse large B-cell lymphoma: a correlative biomarker study. Lancet Oncol. 2015;16:541-9. https://doi. org/10.1016/S1470-2045(15)70106-3. The potential utility of monitoring BCR in plasma DNA for MRD purposes in DLBCL.

105. Rowley JD. Chromosome studies in the non-Hodgkin's lymphomas: the role of the 14;18 translocation. J Clin Oncol. 1988;6:91925. https://doi.org/10.1200/JCO.1988.6.5.919.

106. Okosun J, Bödör C, Wang J, Araf S, Yang CY, Pan C, et al. Integrated genomic analysis identifies recurrent mutations and evolution patterns driving the initiation and progression of follicular lymphoma. Nat Genet. 2014;46:176-81. https://doi.org/10. 1038/ng.2856.

107. Araf S, Wang J, Korfi K, Pangault C, Kotsiou E, Rio-Machin A, et al. Genomic profiling reveals spatial intra-tumor heterogeneity in follicular lymphoma. Leukemia. 2018;32:1261-5. https://doi. org/10.1038/s41375-018-0043-y. Evidence of tumour heterogeneity between separate anatomical lesions in an individual patient.

108. Pasqualucci L, Khiabanian H, Fangazio M, Vasishtha M, Messina $\mathrm{M}$, Holmes AB, et al. Genetics of follicular lymphoma transformation. Cell Rep. 2014;6:130-40. https://doi.org/10.1016/j. celrep.2013.12.027.

109. Pastore A, Jurinovic V, Kridel R, Hoster E, Staiger AM, Szczepanowski M, et al. Integration of gene mutations in risk prognostication for patients receiving first-line immunochemotherapy for follicular lymphoma: a retrospective analysis of a prospective clinical trial and validation in a population-based registry. Lancet Oncol. 2015;16:1111-22. https://doi.org/10.1016/S1470-2045(15)00169-2. Combination of genetic with clinical factors to generate a prognostic scoring system in follicular lymphoma.

110. McCabe MT, Ott HM, Ganji G, Korenchuk S, Thompson C, Van Aller GS, et al. EZH2 inhibition as a therapeutic strategy for lymphoma with EZH2-activating mutations. Nature. 2012;492:10812. https://doi.org/10.1038/nature11606.

111. Raffeld M, Jaffe ES. bcl-1, t(11;14), and mantle cell-derived lymphomas. Blood. 1991;78:259-63.

112. Martín-Garcia D, Navarro A, Valdés-Mas R, Clot G, GutiérrezAbril J, Prieto M, et al. CCND2 and CCND3 hijack immunoglobulin light-chain enhancers in cyclin D1- mantle cell lymphoma.
Blood. 2019;133:940-51. https://doi.org/10.1182/blood-2018-07862151.

113. Eskelund CW, Dahl HJW, Westman M, Kolstad A, Pedersen LB, et al. TP53 mutations identify younger mantle cell lymphoma patients who do not benefit from intensive chemoimmunotherapy. Blood. 2017;130:1903-10. https://doi.org/10.1182/blood-201704-779736.

114. Treon SP, Xu L, Yang G, Zhou Y, Liu X, Cao Y, et al. MYD88 L265P somatic mutation in Waldenström's macroglobulinemia. $\mathrm{N}$ Eng1 J Med. 2012;367:826-33. https://doi.org/10.1056/ NEJMoa1200710.

115. Treon SP, Tripsas CK, Meid K, Warren D, Varma G, Green R, et al. Ibrutinib in previously treated Waldenström's macroglobulinemia. N Engl J Med. 2015;372:1430-40. https://doi.org/10.1056/ NEJMoa1501548.

116. Tiacci E, Trifonov V, Schiavoni G, Holmes A, Kern W, Martelli MP, et al. BRAF mutations in hairy-cell leukemia. N Engl J Med. 2011;364:2305-15. https://doi.org/10.1056/NEJMoa1014209.

117. Tiacci E, Park JH, De Carolis L, Chung SS, Broccoli A, Scott S, et al. Targeting mutant BRAF in relapsed or refractory hairy-cell leukemia. N Engl J Med. 2015;373:1733-47. https://doi.org/10. 1056/NEJMoa1506583.

118. Waterfall JJ, Arons E, Walker RL, Pineda M, Roth L, Killian JK, et al. High prevalence of MAP2K1 mutations in variant and IGHV4-34-expressing hairy-cell leukemias. Nat Genet. 2014;46: 8-10. https://doi.org/10.1038/ng.2828.

119. Sakata-Yanagimoto M, Enami T, Yoshida K, Shiraishi Y, Ishii R, Miyake Y, et al. Somatic RHOA mutation in angioimmunoblastic T cell lymphoma. Nat Genet. 2014;46:171-5. https://doi.org/10. 1038/ng.2872.

120. Rosenquist R, Rosenwald A, Du MQ, Gaidano G, Groenen P, Wotherspoon A, et al. Clinical impact of recurrently mutated genes on lymphoma diagnostics: state-of-the-art and beyond. Haematologica. 2016;101:1002-9. https://doi.org/10.3324/ haematol.2015.134510.

121. Döhner H, Stilgenbauer S, Benner A, Leupolt E, Kröber A, Bullinger L, et al. Genomic aberrations and survival in chronic lymphocytic leukemia. N Engl J Med. 2000;343:1910-6. https:// doi.org/10.1056/NEJM200012283432602.

122. Rigolin GM, Saccenti E, Guardalben E, Cavallari M, Formigaro L, Zagatti B, et al. In chronic lymphocytic leukaemia with complex karyotype, major structural abnormalities identify a subset of patients with inferior outcome and distinct biological characteristics. Br J Haematol. 2018;181:229-33. https://doi.org/10.1111/ bjh.15174.

123. Schroeder HW Jr, Dighiero G. The pathogenesis of chronic lymphocytic leukemia: analysis of the antibody repertoire. Immunol Today. 1994;15:288-94. https://doi.org/10.1016/0167-5699(94) 90009-4.

124. Hamblin TJ, Davis Z, Gardiner A, Oscier DG, Stevenson FK. Unmutated $\operatorname{Ig} \mathrm{V}(\mathrm{H})$ genes are associated with a more aggressive form of chronic lymphocytic leukemia. Blood. 1999;94:1848-54. https://doi.org/10.1182/blood.V94.6.1848.

125. Thompson PA, Tam CS, O'Brien SM, Wierda WG, Stingo F, Plunkett W, et al. Fludarabine, cyclophosphamide, and rituximab treatment achieves long-term disease-free survival in IGHVmutated chronic lymphocytic leukemia. Blood. 2016;127:303-9. https://doi.org/10.1182/blood-2015-09-667675.

126. International CLL-IPI working group. An international prognostic index for patients with chronic lymphocytic leukaemia (CLL-IPI): a meta-analysis of individual patient data. Lancet Oncol. 2016;17: 779-90. https://doi.org/10.1016/S1470-2045(16)30029-8.

127. Malcikova J, Pavlova S, Kozubik KS, Pospisilova S. TP53 mutation analysis in clinical practice: lessons from chronic lymphocytic leukemia. Hum Mutat. 2014;35:663-71. https://doi.org/10.1002/ humu. 22508 . 
128. Rossi D, Khiabanian H, Spina V, Ciardullo C, Bruscaggin A, Famà R, et al. Clinical impact of small TP53 mutated subclones in chronic lymphocytic leukemia. Blood. 2014;123:2139-47. https://doi.org/10.1182/blood-2013-11-539726.

129. Schuh AH, Parry-Jones N, Appleby N, Bloor A, Dearden CE, Fegan C, et al. Guideline for the treatment of chronic lymphocytic leukaemia: a British Society for Haematology Guideline. Br J Haematol. 2018;182:344-59. https://doi.org/10.1111/bjh.15460. Guidelines on the use of targeted therapies in TP53 disrupted CLL.

130. Ahn IE, Underbayev C, Albitar A, Herman SE, Tian X, Maric I, et al. Clonal evolution leading to ibrutinib resistance in chronic lymphocytic leukemia. Blood. 2017;129:1469-79. https://doi.org/ 10.1182/blood-2016-06-719294.

131. Lazarian G, Guièze R, Wu CJ. Clinical implications of novel genomic discoveries in chronic lymphocytic leukemia. J Clin Oncol. 2017;35:984-93. https://doi.org/10.1200/JCO.2016.71.0822.

132. Chng WJ, Dispenzieri A, Chim CS, Fonseca R, Goldschmidt H, Lentzsch S, et al. IMWG consensus on risk stratification in multiple myeloma. Leukemia. 2014;28:269-77. https://doi.org/10. 1038/leu.2013.247.

133. Sonneveld P, Avet-Loiseau H, Lonial S, Usmani S, Siegel D, Anderson KC, et al. Treatment of multiple myeloma with highrisk cytogenetics: a consensus of the international myeloma working group. Blood. 2016;127:2955-62. https://doi.org/10.1182/ blood-2016-01-631200.
134. Pawlyn C, Davies FE. Toward personalized treatment in multiple myeloma based on molecular characteristics. Blood. 2019;133: 660-75. https://doi.org/10.1182/blood-2018-09-825331. Utility of genomic testing in personalising treatment in myeloma.

135. Perrot A, Corre J, Avet-Loiseau H. Risk stratification and targets in multiple myeloma: from genomics to the bedside. Am Soc Clin Oncol Educ Book. 2018;38:675-80. https://doi.org/10.1200/ EDBK 200879.

136. Robiou du Pont S, Cleynen A, Fontan C, Attal M, Munshi N, Corre J, et al. Genomics of multiple myeloma. J Clin Oncol. 2017;35:963-7. https://doi.org/10.1200/JCO.2016.70.6705.

137. Perrot A, Lauwers-Cances V, Corre J, Robillard N, Hulin C, Chretien ML, et al. Minimal residual disease negativity using deep sequencing is a major prognostic factor in multiple myeloma. Blood. 2018;132:2456-64. https://doi.org/10.1182/blood-201806-858613.

138. Turnbull C, Scott RH, Thomas E, Jones L, Murugaesu N, Pretty FB, et al. The 100000 genomes project: bringing whole genome sequencing to the NHS. BMJ. 2018;361:k1687. https://doi.org/10. 1136/bmj.k1687.

139. https://www.england.nhs.uk/publication/national-genomic-test-directories/. Accessed 12/10/2019.

Publisher's Note Springer Nature remains neutral with regard to jurisdictional claims in published maps and institutional affiliations. 